\title{
UNDER CONSTRUCTION: A CloSE EXAMINATION OF RECENT CONSTRUCTION LAW DEVELOPMENTS AND THEIR IMPACT ON THE OIL AND GAS INDUSTRY
}

\author{
KEVIN E. BARR ${ }^{*}$ AND THERON W. DAVIS ${ }^{* *}$
}

\begin{abstract}
This article surveys recent construction-related case law pertaining to the oil and gas sector, and examines how these decisions impact the law of bonding, tendering, liens, and arbitration. The authors review jurisprudence, legislation, and contractual language in these areas, and provide a critical analysis of the law in order to suggest improvements and anticipate future innovations. The authors also provide practical advice regarding mechanisms that owners, contractors, and subcontractors can employ to protect themselves from risks and uncertainties in contemporary construction law, with a view to avoiding disputes and if necessary, resolving them. This article serves both as an illustration of the structure of contemporary construction law as-built, and as a blueprint for those aspects of the law that are still under construction.
\end{abstract}

\section{TABLE OF CONTENTS}

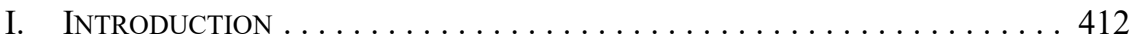

II. BONDING: BENEFITS AND LIABILITIES . . . . . . . . . . . . . . . . . . . . 413

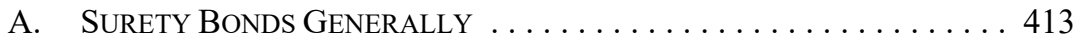

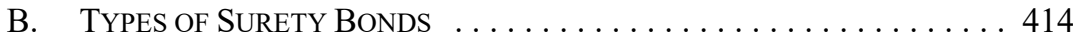

C. The Supreme Court of CANADA's Decision in VALARD . . . . . 416

D. Thoughts and Reflections: We Are Where We Are . . . . . . . 422

III. TENDERING: BALANCING INTERESTS AND FAVOURING THE OWNER . . . . 424

A. The Alberta Court of Appeal's Decision

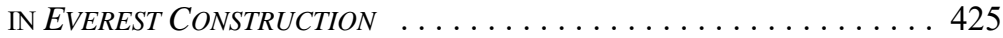

B. The British COLUMBIA SUPREME COURT's DECISION IN J. COTE \& SON EXCAVATING . . . . . . . . . . . . . . 428

C. The British COlumbia COURT OF APPEAL'S

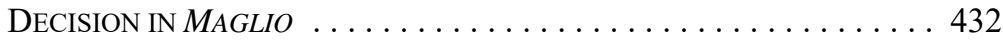

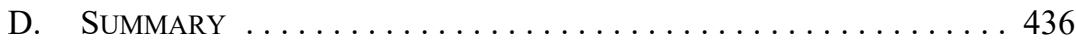

IV. LIENS ON OIL AND GAS PROJECTS:

EVERYTHING BUT THE KITCHEN SINK . . . . . . . . . . . . . . 436

A. The INTERNATIONAL BROTHERHOOD AT THE QUEEN'S BENCH . . . 437

B. TROtTER AND Morton AT THE QUEEN's BenCH . . . . . . . . . . 443

* Kevin Barr is a partner in the Calgary office of Borden Ladner Gervais LLP and he practises primarily in the areas of commercial litigation and bankruptcy and insolvency. His commercial litigation practice is concentrated particularly in the area of construction, including energy-related, matters. Kevin regularly acts for owners, contractors, and lenders on a variety of construction matters. He regularly defends and prosecutes claims pertaining to all forms of construction and energy liens. Kevin has delivered a number of presentations to industry groups on a variety of construction matters including the Builders' Lien Act and bid rigging. Kevin is also an experienced insolvency practitioner. He regularly acts for lenders, debtors, suppliers, purchasers, trustees, and receivers in a variety of proceedings. Kevin is the former chair of the Canadian Bar Association - Insolvency and Restructuring Subsection.

Theron Davis is an associate in the Construction Group at Borden Ladner Gervais LLP. Theron has a construction and surety practice that focuses on all aspects of the construction industry. He acts for owners, developers/contractors, and subcontractors in various matters, including the preservation and enforcement of builders' lien rights. Theron is an active speaker and writer on a variety of constructionrelated topics including the Builders' Lien Act, dispute resolution, and claims. 
C. DAVidSON Well DRILling's RECEIVER

AT THE QUEEN'S BENCH $\ldots \ldots \ldots \ldots \ldots \ldots \ldots \ldots \ldots \ldots$

V. Arbitration: ChoOse Your JuRisdiction Wisely . . . . . . . . . . . 451

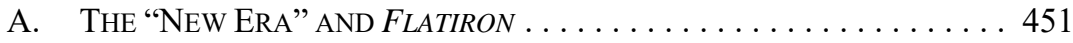

B. Dealing With Multiple Litigants: SeEking

TO COMMENCE CONSOLIDATED ARBITRATIONS . . . . . . . . . . . . . 456

C. Settling With Some, But nOt Others:

THE IMPACT OF PIERRINGER AGREEMENTS . . . . . . . . . . . . 460

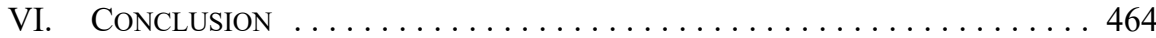

\section{INTRODUCTION}

Oil and gas construction projects are complex, subject to a host of statutory schemes, can incorporate hundreds of contracting parties, and regularly result in litigation. The oil and gas industry continues to drive the Canadian economy and is a source of some of the country's largest construction projects. A strong energy sector is critical to ensure Canada remains a vibrant and competitive member of the global community.

Canadian courts have recently delivered a number of construction-related decisions that impact bonding, tendering, liens, and arbitration in the oil and gas industry. A review of this jurisprudence demonstrates that the oil and gas industry is at the forefront of testing the boundaries of construction law. The trial of these disputes enriches the area of construction law and, in return, the principles of construction law are interwoven with the everyday operations of oil and gas stakeholders.

There are many legal actors responsible for nurturing this sector of the economy. First, judges are required to render decisions that are fair, principled, and certain so that industry participants can invest without fear of arbitrary losses. Second, the government demonstrates a deliberate effort to customize Canadian legislation in a way that specifically promotes and protects the oil and gas industry through statutory mechanisms, like those in the provincial builders' lien acts. Last, but not least, contracting parties bear their own responsibility in effectively drafting and negotiating legally enforceable agreements that contain clear terms.

An understanding of how this interconnected web of jurisprudence, contracts, and legislative drafting directs the outcome of disputes can increase certainty in the industry. Finding the best strategic path to avoid, or resolve, disputes is vital to the success of any business. Where unresolved conflicts in the law exist, interested parties should remain vigilant to avoid the associated risks that arise with litigation.

Oil and gas law is a highly specialized area, but as it relates specifically to construction projects and contracting there is much to be learned from the outcomes and reasoning provided by the judiciary in foundational construction law cases relating to industry specific circumstances. This article canvasses a number of recent decisions that highlight common pitfalls and residual uncertainties in the law. 


\section{BONDING: BENEFITS AND LIABILITIES}

The construction industry regularly relies on surety bonds to guarantee performance and limit exposure to lawsuits or financial loss. However, recent case law has established that some types of bonds are a double-edged sword as they can be both a benefit and a potential liability. This was articulated in the recent Supreme Court of Canada decision of Valard Construction Ltd. v. Bird Construction Co. ${ }^{1}$ In Valard, the Supreme Court held that an obligee could be liable to a lower tier beneficiary for failing to provide full disclosure respecting the existence of a labour and material payment bond (L\&M Bond) to subcontractors and suppliers who furnish goods and services to a project. Although not expressly indicated within the four corners of the L\&M Bond, the general law on fiduciary duties played a key role in the outcome of the case.

Those wishing to implement or require bonds on their projects should be aware of the accompanying obligations, rights, and duties. Conversely, those working on projects where bonds might be in place should still take due care in making timely inquiries about their existence.

\section{A. Surety Bonds Generally}

Generally, a surety bond is a type of guarantee agreement, wherein the surety undertakes to correct the default of the principal in respect of its obligations to the obligee. In the construction industry, this arrangement is most commonly organized between an owner as an obligee, a general contractor as principal, and a bonding or insurance company as the surety. The nature of this tripartite relationship differentiates surety bonds from contracts of insurance. For example, the surety, unlike an insurer, can influence against the occurrence of the principal's default. ${ }^{2}$ By contrast, an insurer is usually only called upon to pay the loss resulting from a defined contingency.

Surety bonds also differ from other types of guarantee agreements. ${ }^{3}$ This difference primarily stems from the surety's entitlement to the full range of rights and defences that the principal may have had. ${ }^{4}$ Justice Adams succinctly captured this idea when he stated that, "the liability of the surety is collateral and dependent upon the existence of an enforceable obligation against the principal." The liability of a surety is also limited to the damages actually suffered by the obligee as a result of the principal's non-performance of the underlying contract.

For example, standby letters of credit, performance guarantees, and letters of intent. For further discussion, see Standard Trust Co v Mortgage Insurance Co of Canada, 1992 CarswellOnt 139 (WL Can) (Ct J (Gen Div)) at paras 12-15 [Standard Trust].

Tanar Industries Ltd v Outokumpu Ecoenergy, Inc, 1999 ABQB 597 at para 40 [Tanar Industries]. Standard Trust, supra note 3 at para 15, citing Herman J Wilton-Siegel, "International Business Agreements: Security for Payment" in Canadian Institute Proceedings (1990), The Art of Negotiating and Drafting International Commercial Contracts at 43-45. 
Other notable features of surety bonds include that the stipulated maximum exposure of the surety within the form of the bond is merely an upper limit, and is not a set payment owing upon default. ${ }^{6}$ Commonly, the form of the bond will also allow the surety to perform the principal's obligations in lieu of paying cash to the obligee. Further, a surety may be relieved of its liability if the obligee has done something to prejudice the interests of the surety. ${ }^{7}$

\section{B. TYPES OF SURETY BONDS}

Surety bonds come in varied forms. The language of the bond circumscribes the parties' rights and defines the associated obligations and benefits. The scope of the surety's liability is a matter of contractual interpretation. ${ }^{8}$ In the context of construction for oil and gas projects, there are three relevant types of surety bonds: (1) bid bonds, (2) performance bonds, and (3) L\&M Bonds.

A bid bond guarantees that the principal will enter into a formal contract with the obligee upon being selected as the winning bidder in a tender process. ${ }^{9}$ Bid bonds have largely replaced the old approach of requiring bidders to provide a security deposit, usually cash or certified cheque, as part of their bid. Owners require such security to discourage the submission of frivolous bids, but the old approach tied up significant capital, especially when bidders were bidding on multiple projects.

In the event of a principal's default under a bid bond, the surety is usually required to pay the difference between the amount the principal would have charged for the work and the cost of arranging the contract with another bidder. ${ }^{10}$ The surety does not, however, guarantee the performance of the contract. A bid bond merely ensures that the principal enters into the contract.

While this is generally true, see OHL Construction Canada v Continental Casualty Company, 2013 ONSC 4043 at para 18: "The plaintiffs highlight the fact that there is no Canadian authority that stands for the proposition argued by the defendants that a claim against a surety for an amount in excess of a performance bond cannot succeed."

$7 \quad$ Kenneth W Scott, QC \& R Bruce Reynolds, Scott and Reynolds on Surety Bonds (Toronto: Thomson Reuters, 2017) at 7.3.

$8 \quad$ See e.g. Johnson Enterprises Ltd v RW Landmark Construction Ltd, 1993 CarswellBC 1177 (WL Can) (SC); Harris Steel Ltd v Alta Surety Co, [1993] 119 NSR (2d) 61 (CA).

$9 \quad$ See e.g. Vaughan (Town) v Alta Surety Co, 1990 CarswellOnt 678 (H Ct J) at para 19.

$10 \quad R v$ Ron Engineering \& Construction (Eastern) Ltd, [1981] 1 SCR 111 at 121-24 [Ron Engineering]. See also Canadian Construction Documents Committee, "Bid Bond" (Standard Construction Document), CCDC 220-2002 (CCDC, 2002): "[T]he Principal and the Surety will pay to the Obligee the difference in money between the amount of the bid of the Principal and the amount for which the Obligee legally contracts with another party to perform the work if the latter amount be in excess of the former." 
A performance bond guarantees that the principal will fulfill its obligations as outlined in the underlying contract. Performance bonds are commonly required on construction projects. The new Ontario Construction Act requires that a contractor (the principal) furnish both a performance bond and an L\&M Bond "if the owner [the obligee] is the Crown, a municipality or a broader public sector organization." ${ }^{11}$ As lien legislation across the country continues to evolve, this may become a common feature everywhere.

When a principal under a performance bond is in default of its contractual obligations to the obligee, and there is no defence for the default, the surety is usually entitled to pursue one of three options as stated in the Canadian Construction Documents Committee (the $\mathrm{CCDC}^{12}$ 221-2002 Standard Form of Performance Bond. The options are: (1) remedy the default; (2) complete the contract in accordance with its terms and conditions; or (3) obtain a bid for submission to the obligee and following an award of a contract to the lowest responsible bidder, pay the associated cost to complete the work. ${ }^{13}$

An L\&M Bond guarantees that the subcontractors, suppliers, and possibly other lower tiers on the construction pyramid are paid for the work and materials they provide towards the betterment of the project. However, an L\&M Bond differs from other forms of surety bonds, as

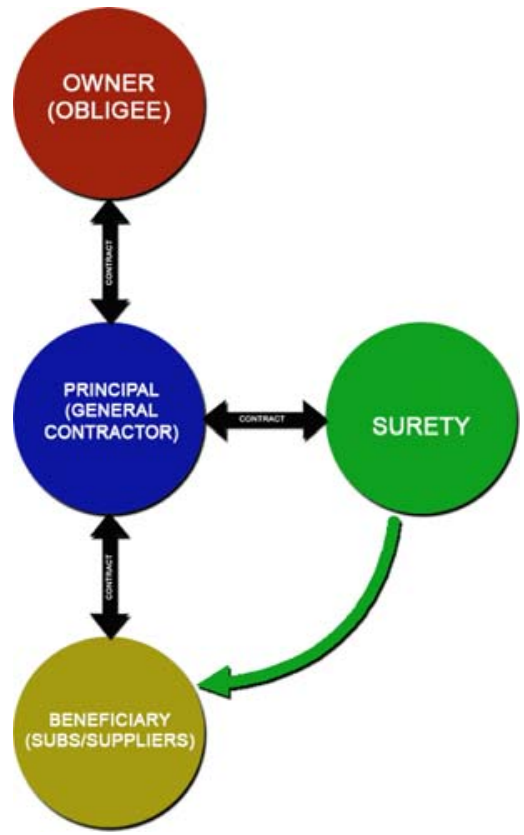

Figure 1.1 the obligee is not the only beneficiary under the instrument. In the context of L\&M Bonds, the underlying contract is between the principal and the obligee, but the subcontractors and suppliers also benefit directly from the L\&M Bond. Further, under an L\&M Bond the principal's performance is measured against its obligations to the subcontractors and suppliers below it, not the obligee. These obligations are not, however, necessarily mutually exclusive.

Canadian Construction Documents Committee: CCDC documents are developed through a consultative process with representatives from all sectors in the construction industry. These consensus-based documents carry the endorsement of the four constituent national organizations. A lawyer from the Canadian Bar Association, construction law section, also sits as an ex officio member of the committee (CCDC, "About CCDC" (2019), online: <cedc.org/about>).

13 Please note, the Federal Form of Performance Bond provides completely different options and leaves the choice to the Obligee. 
In an L\&M Bond there is no privity of contract between the unnamed third-party beneficiaries and the surety or obligee. Consequently, in order to avoid the rule against thirdparty beneficiaries claiming on an instrument to which they are not a party, ${ }^{14}$ an L\&M Bond creates, through the language of the bond, a trust relationship between the obligee, as a trustee, and the lower tier beneficiaries. ${ }^{15}$

In order for the surety's liability to crystallize, payment by the principal to the beneficiaries, subcontractors, and suppliers must be due. ${ }^{16}$ As before, in the face of liability, the surety is still entitled to raise any defence the principal would otherwise be entitled to raise. ${ }^{17}$

An L\&M Bond will only cover the cost of materials, labour, and services reasonably used in the furtherance of the work as required in the contract between the principal and the obligee. For example, an L\&M Bond will not respond to claims for damages relating to delay, increased overhead, or loss of profits. ${ }^{18}$

\section{The SUPREMe COURT OF CANADA'S DECISION IN VALARD}

The majority in Valard held that, in general, a trustee must inform beneficiaries that a trust exists whenever a beneficiary would be unreasonably disadvantaged by not knowing. ${ }^{19}$

In Valard, Suncor Energy Inc. (Suncor) hired the respondent, Bird Construction Company (Bird), as general contractor for the construction of a project described as the Suncor Energy MEM 2 Bay Shop Expansion (the Project) on a Suncor oil sands site near Fort McMurray, Alberta. Bird entered into a subcontract with Langford Electric Ltd. (Langford) for electrical work. The contract between Bird and Langford required a bond be put in place. The form of the bond was a CCDC 222-2002 Standard Labour and Material Payment Bond (Trustee Form), within which Langford was named as principal, Bird as the obligee/trustee, and the Guarantee Company of North America (GCNA) as the surety. Langford then further subcontracted with Valard Construction Ltd. (Valard) for, among other things, certain directional drilling services on the Project. (CA), aff'd [1983] 1 SCR 513. See also Tobin Tractor (1957) Ltd v Western Surety Co (1963), 40 DLR (2d) 231 (Sask QB).

15 See e.g. Canadian Construction Documents Committee, "Labour and Material Payment Bond (Trustee Form)," (Standard Constuction Document), CCDC 222-2002 (CCDC, 2002), which states: "The Principal and the Surety, hereby jointly and severally agree with the Obligee, as Trustee" and further that, "every Claimant ... may as a beneficiary of the trust herein provided for, sue on this Bond."

16 Arnoldin Construction \& Forms Ltd v Alta Surety Co, [1995] 137 NSR (2d) 281 at para 41 (CA).

17 Kesmat Investment Inc $v$ Industrial Machinery Company Limited and Canadian Indemnity Company, [1985] 70 NSR (2d) 341 at para 13 (SC (AD)). See also Tanar Industries, supra note 4 at para 41. Dominion Bridge-Ontario v Stephen Sura (Canada) Ltd, [1997] OJ No 3023 (QL) at paras 75-79 (Ct J (Gen Div)).

Valard SCC, supra note 1 at para 2. 
Ultimately, Valard went unpaid and claimed against Langford. Approximately one year after it had started work on the project, Valard obtained a default judgment in the amount of $\$ 660,000.17$ against Langford. After obtaining default judgment, Valard inquired with Bird as to whether a bond was present on the project. Bird acknowledged that a bond was in place, and provided Valard with GCNA's contact information. Valard submitted its claim against the bond, but was denied for being out of time. The bond stipulated that any claimant under the bond had to provide written notice within 120 days from the last day of work.

After the denial, Valard commenced an action against GCNA. Valard later amended its claim to add Bird as a defendant. Eventually, Valard filed a notice of discontinuance against GCNA and further amended its claim to proceed only against Bird for breaching its fiduciary duty to inform Valard of the bond's existence within the relevant period. ${ }^{20}$

\section{The LOWER COURTS’ DeCiSIONS AND THE LAW AS IT WAS}

The trial judge dismissed Valard's action, awarding Bird costs on a full indemnity basis. ${ }^{21}$ Formerly, an obligee under an L\&M Bond had no positive legal duty to disclose the existence of the bond to the beneficiaries thereunder. ${ }^{22}$ Further, the trial judge was of the opinion that, much like other types of surety bonds, the purpose of the bond was to protect the obligee. Bird was under no obligation to take any action to enforce the provisions of the bond. $^{23}$

Interestingly, at trial Valard argued "that Bird could easily have posted the Bond on the bulletin board in Bird's office trailer on the site, distributed copies of the Bond, or required Langford to take reasonable steps to notify its subcontractors and material suppliers of the existence of the Bond." ${ }^{24}$ In response, the trial judge concluded that Bird was not under any such obligation and that a "simple standard inquiry by Valard would be a more reliable means of obtaining the information." 25 As discussed below, the majority of the Supreme Court focused on the actions of the obligee as a trustee, refusing to impose any obligation on a beneficiary to protect its own interests.

The Alberta Court of Appeal dismissed Valard's appeal and agreed with the trial judge. Again, the Court determined that a "contractor in the position of the respondent has no legal duty to inform any potential claimant about the existence of a labour and material payment bond, unless and until a clear and unequivocal request for information about the bond is made. ${ }^{26}$ Here, the Court pointed to mechanisms under the Alberta Builders' Lien Act that

Valard Construction Ltd v Bird Construction Company, 2015 ABQB 141 at para 15 [Valard QB]. Ibid at paras 94-95.

Dolvin v Trisura Guarantee, 2014 ONSC 918 at para 62; Dominion Bridge Co Ltd v Marla Construction Co Ltd, [1970] 3 OR 125 at 129 (Co Ct).

Valard QB, supra note 20 at para 79.

Ibid at para 84 .

Ibid at para 85 .

Valard Construction Ltd v Bird Construction Company, 2016 ABCA 249 at para 28 [Valard CA]. 
provide unpaid claimants access to information. ${ }^{27}$ In other words, there was no excuse for Valard to have been caught by surprise regarding the existence of the bond.

\section{THE SUPREME COURT OF CANADA’s MAJORITY DECISION}

In rendering its decision, the majority of the Supreme Court acknowledged that the language of the L\&M Bond, a standard CCDC 222-2002, did not expressly impose a duty on Bird to protect the interests of the third-party beneficiaries. For example, the L\&M Bond did not expressly require Bird to inform those potential beneficiaries of the existence of the bond. However, the majority concluded that the language of the bond is only the "main source" of the obligee/trustee's obligations and that where the instrument is silent, the general law of trusts steps in. ${ }^{28}$

The majority determined that under the general law of trusts, Bird owed Valard a duty. Specifically the majority held that "wherever a beneficiary would be unreasonably disadvantaged not to be informed of a trust's existence, the trustee's fiduciary duty includes an obligation to disclose the existence of the trust. ${ }^{, 29}$ The crux of the issue therefore became what constitutes an unreasonable disadvantage. According to the majority, such a determination required an evaluation of the "nature and terms of the trust and the social or business environment in which it operates." ${ }^{30}$ In other words, determining what constitutes an unreasonable disadvantage depends on the context and is up to the Court's discretion.

In light of the particular facts of this appeal, the majority determined that L\&M Bonds are not regularly used in private oil sands construction. The majority asserted that Valard's evidence on the regularity of L\&M Bonds in these circumstances, advanced by Valard's project manager John Cameron Wemyss, was uncontested. The majority also criticized the dissenting opinion on this point, stating with emphasis that "the fact here was that labour and material payment bonds were uncommon on private oilsands construction projects." ${ }^{31}$

As a result of that finding, by failing to disclose the existence of the bond Bird breached the duty it owed, and Valard was unreasonably disadvantaged by being deprived of its ability to claim the benefit to which it was entitled.

However, the majority made no mention of the lower Courts' findings that Wemyss did not request the details of any of the contracts as between Langford and Bird, nor Bird and Suncor. ${ }^{32}$ Nor did Wemyss notify Bird or Suncor that Langford had not paid its accounts. ${ }^{33}$ In fact, Wemyss was reluctant to "rock the boat" and chose not to disclose Langford's failure to pay. ${ }^{34}$ The lower Courts also found that Wemyss was familiar with L\&M Bonds, that he

RSA 2000, c B-7, s 33 [BLA]. See also Valard CA, supra note 26 at para 28.

Valard SCC, supra note 1 at para 15.

Ibid at para 2 .

Ibid at para 19

Ibid at para 23 [emphasis in original].

Valard QB, supra note 20 at para 23.

Valard CA, supra note 26 at para 72.

Ibid; Valard QB, supra note 20 at para 24. 
knew they had terms and notice provisions, and that he had previously claimed against a surety for an unpaid account. ${ }^{35}$ Wemyss also testified to the fact that he was personally surprised by the existence of an L\&M Bond on an oil sands project, despite the fact that they were common in similar public projects. ${ }^{36}$

The majority went on to acknowledge that L\&M Bonds serve to protect the obligee/trustee "from the risk of work stoppages, liens and litigation over payment." ${ }^{37}$ As far as the obligee is protected, L\&M Bonds are similar to other types of surety bonds. However, the majority asserted that for these benefits to accrue to the obligee, the beneficiaries must be made aware of their right to claim on the bond. The majority did not address that in this case the beneficiary intentionally withheld information from the obligee/trustee of Langford's failure to pay. In fact, such notice was not given until almost a year after Valard had left the site, and approximately one month after Valard had obtained default judgment. ${ }^{38}$

Nonetheless, the majority concluded that because the proper operation of an L\&M Bond requires a beneficiary to claim against the bond, the obligee should be required to disclose whether such a bond exists. ${ }^{39}$ The majority considered only what Bird should have reasonably done in the circumstances. ${ }^{40}$ The "nature and terms of the trust and the social or business environment in which it operates," 41 apparently did not take into consideration any of the actions, omissions, or inaction of the beneficiary.

\section{THE SUPREME COURT OF CANADA's DisSENTING OPINION}

In the opening paragraphs of the dissenting opinion, Justice Karakatsanis led with the following:

For over 45 years, labour and material payment bonds have been commonly used to secure contractual obligations in the construction industry.

For decades, the industry understanding and practice has been that the trustee is under no obligation to inform the beneficiaries of the existence of the trust and that claimants are expected to enquire as to the existence of a bond. My colleague would hold otherwise. I cannot agree.

In my view, general trust law principles do not imply the obligation to notify potential claimants in this commercial context. Equity imposes different obligations depending on the context. In the circumstances of the construction industry, Bird Construction Company was not under an obligation to inform potential claimants of the existence of the bond. Rather, it was required to respond accurately when asked. Imposing

Valard CA, ibid at paras 5, 73 .

Ibid at para 79.

Valard SCC, supra note 1 at para 22.

Valard CA, supra note 26 at paras 6, 75.

Valard SCC, supra note 1 at para 22.

Ibid at para 29.

Ibid at para 19. 
a mandatory obligation on the trustee to inform potential claimants of the bond's existence transforms what was a beneficial risk-management tool into a significant liability. ${ }^{42}$

Justice Karakatsanis diverged from the majority on two important issues. First, she refused to accept that although L\&M Bonds are widespread in the construction industry they should be treated differently in an allegedly niche part of the market. Second, she refused to accept that general trust principles create a significant liability for parties within this particular commercial context.

There were many points of agreement among the majority and dissenting opinions. Both the majority and Justice Karakatsanis agreed that the CCDC 222-2002 creates a trust relationship. However, as Justice Karakatsanis pointed out, the CCDC 222-2002 is not silent on the obligations of the obligee in its role as trustee. ${ }^{43}$ The language of the bond states specifically that

\footnotetext{
the Obligee is not obliged to do or take any act, action or proceeding against the Surety on behalf of the Claimants, or any of them, to enforce the provisions of this Bond. If any act, action or proceeding is taken either in the name of the Obligee or by joining the Obligee as a party to such proceeding, then such act, action or proceeding, shall be taken on the understanding and basis that the Claimants, or any of them, who take such act, action or proceeding shall indemnify and save harmless the Obligee against all costs, charges and expenses or liabilities incurred thereon and any loss or damage resulting to the Obligee by reason thereof. Provided still further that, subject to the foregoing terms and conditions, the Claimants, or any of them may use the name of the Obligee to sue on and enforce the provisions of this Bond. ${ }^{44}$
}

Notably, the obligee was expressly not required to do or take any action to enforce the provisions of the bond.

Further, and in line with the majority's decision, Justice Karakatsanis conveyed that the words of the instrument define the obligations of the parties at first instance, but that these obligations can be enhanced by the general laws of equity. ${ }^{45}$ Equity is responsive to the particular circumstances of the parties. The approach espoused by Justice Karakatsanis was, therefore, the same as that of the majority: one must consider the nature and terms of the instrument and the social or business environment in which it operates. ${ }^{46}$

Justice Karakatsanis, however, diverged from the majority by differentiating the contexts in which a duty to disclose the existence of a trust has historically been present. Disclosure of the existence of a trust was historically required where a trustee was responsible to a family trust or a trust for a minor. ${ }^{47}$ In both instances, the beneficiaries are incapable of knowing about the existence of the trust and are accordingly deserving of equity's protection.

Ibid at paras $42-45$.

Ibid at para 55.

Ibid, Appendix at para 2.

Valard SCC, supra note 1 at para 58.

Ibid at para 60 .

Ibid at para 61 . 
The circumstances of this case were drastically different. Not only was Valard capable of making a "simple inquiry," it had legal recourse to compel an answer. For example, as clearly pointed out by the Alberta Court of Appeal, an unpaid subcontractor or supplier on a construction project may, pursuant to section 33 of the $B L A$, compel the disclosure of information that would inform a potential beneficiary of its rights under a bond. ${ }^{48}$

According to Justice Karakatsanis, it was important to identify that Valard was not an infant beneficiary in need of equity's protection. Valard was a commercial entity engaged in a $\$ 600,000$ business venture that was undoubtedly one of many. Furthermore, the facts showed that Valard's project manager was familiar with bonds. Bonds of this type are common on public projects and are increasingly widespread in the private construction industry. ${ }^{49}$ Valard also intentionally withheld any indication that Langford had failed to pay.

Justice Karakatsanis also pointed out that beneficiaries under a trust generally only have the power to hold the trustee accountable for its administration of the trust property and to enforce the terms of the trust. ${ }^{50}$ The trust "property" in an L\&M Bond is the right to sue the surety for the principal's failure to perform on the terms of the underlying contract. ${ }^{51}$ The terms of the bond were clear that the obligee was under no obligation to commence an action on behalf of the claimants, and that the claimants had a limited amount of time within which to bring their claim. Justice Karakatsanis concluded "equity does not generally demand more in the context of the construction industry." 52

Lastly, Justice Karakatsanis considered whether the fact that the L\&M Bond was in place on an oilsands project should change the analysis. In short, she thought not. First, Justice Karakatsanis pointed out that establishing different obligations for obligees/trustees depending on the region or sector of the construction industry creates serious uncertainty. ${ }^{53}$ Secondly, she disputed whether the trial judge even found that L\&M Bonds were uncommon in the oil sands. Wemyss testified at trial that he had not, in his ten years of experience working with Valard in the oil sands, encountered an L\&M Bond. However, the trial judge noted that Wemyss' individual perspective of the industry might have been shaped by the fact that during those ten years he had never asked about L\&M Bonds. ${ }^{54}$ In Justice Karakatsanis' opinion, that was insufficient to amount to a determinative finding of fact that L\&M Bonds are uncommon in those circumstances.

Valard CA, supra note 26 at para 22.

Valard SCC, supra note 1 at para 51.

Ibid at para 58 .

Ibid at para 4.

Ibid at para 66 .

Ibid at para 68 .

Valard QB, supra note 20 at para 86. 


\section{Thoughts And Reflections: We Are Where We Are}

A striking feature of the Supreme Court's decision in Valard SCC is that the majority appears to have gone out of its way to ensure that Valard, which had no part in the formation of the bond, received the benefit thereunder. By contrast, the one party whom the instrument was intended to protect was ordered to pay for breaching a previously non-existent duty.

As mentioned above, the majority did not account for the beneficiary's action or inaction. In its decision, the majority asserted that for the benefits under an L\&M Bond to accrue to the obligee, the beneficiaries must be made aware of their right to claim on the bond. ${ }^{55}$ However, without any notice from the beneficiary that a right to claim may have arisen, it seems inequitable that the trustee should be said to have breached its obligations. In that situation, the trustee is not aware of any "property" to manage on the beneficiary's behalf.

The majority relied on Re Beaudette Estate for the principal duties of a trustee. ${ }^{56}$ However, the majority did not include the fourth duty listed in Beaudette Estate. The four duties of a trustee described in Beaudette Estate are as follows:

(a) No trustee may delegate his office to others, The Canadian Encyclopedic Digest (Western), 3rd ed. vol. 33 , at p. 144-103.

(b) No trustee may profit personally from his dealings with the trust property, the beneficiaries or as a trustee, Royal Bank v. Foger, Rubinoff (1991), 5 O.R. (3d) 734 (C.A.).

(c) A trustee must act honestly and with that level of skill and prudence which would be expected of the reasonable man of business administering his own affairs, Davies v. Nelson, [1928] 1 D.L.R. 254 (C.A.).

(d) A trustee is a fiduciary and must manage the trust property solely for the beneficiary of the trust, Waters, D.W.M., Law of Trusts in Canada, 2d ed. at p.10. ${ }^{57}$

The second and fourth fundamental duties of a trustee from Beaudette Estate, and the principal right of a beneficiary to hold the trustee accountable for the administration of the trust ${ }^{58}$ all logically relate to the trustee having possession or knowledge of trust "property." According to the majority in Valard, the obligee/trustee was "holding in trust for the beneficiaries their right to claim against and recover from the Guarantee Company." 59

Until a beneficiary notifies the trustee that a right to claim against the L\&M Bond has arisen, the trustee cannot be said to be misappropriating the trust property. The old rule, where a duty to disclose only arose once notice of a claim had been given, made sense in that

Valard SCC, supra note 1 at para 17.

Ibid at para 17; Re Beaudette Estate, 1998 ABQB 689 (Surr Ct) [Beaudette Estate].

Beaudette Estate, ibid at para 26.

Valard SCC, supra note 1 at para 18.

Ibid at para 4 . 
respect. In effect, it is unusual that a trustee be held responsible for breaching its duties and mismanaging the trust "property" when it does not have any reason to know that the "property" has yet come in existence.

To the above, the majority would likely respond that the proper operation of an L\&M Bond, which is aimed at avoiding "risk of work stoppages, liens and litigation over payment," affirms rather than negates the expectation that an obligee/trustee provide notice of the bond's existence. ${ }^{60}$ Without providing notice, the third-party beneficiaries may lose their right to claim on the bond and the obligee/trustee would no longer have the protection of the surety paying amounts owing. This imposes an overwhelming burden on the trustee to provide notice to those potentially impacted contractors.

In Valard, the claimant failed to make timely inquiries and further elected not to notify the obligee/trustee that the principal had failed to meet its payment obligations until more than a year after the claimant had left the site and many months after the deadline to make a claim under the L\&M Bond had expired. It is not hard to imagine other circumstances where suppliers and or sub-subcontractors remain completely unknown to the obligee/trustee and never attend on site. In short, the class of third-party beneficiaries can conceivably be indeterminate and ascribing responsibility to notify these parties seems unfair.

The majority has created a new positive duty on trustees to disclose the existence of a bond where the beneficiary would be unreasonably disadvantaged by not knowing. The trustee may not, however, know who the beneficiary is, nor whether the trust property, being the right to bring a claim, yet exists.

Both the majority and the dissent appear to have focused on the nature and terms of the bond instrument and the social or business environment in which it operates in determining liability. The majority determined, based on a select portion of one witness' evidence, and seemingly in spite of a number of other details, that the business environment and terms of the instrument were such that the obligee had breached its duty and unfairly disadvantaged the beneficiary. Conversely, the dissenting opinion referred regularly to the long history of these bonds in the construction industry, that it was reasonable to assume these bonds were sufficiently known, ${ }^{61}$ and that to treat these bonds differently would create instability and uncertainty. ${ }^{62}$ 
Regardless of which camp has the best grasp on the reality of the industry, those wishing to continue to use L\&M Bonds should take the following precautions:

\section{Delineate the Class of Third-Party Beneficiaries Carefully}

Though the standard form CCDC 222-2002 creates only one tier of beneficiaries, those having a direct contract with the principal, other forms of L\&M Bonds can create multiple tiers. It is critically important, as an obligee or surety, to clearly understand what classes of potential third-party beneficiaries may exist.

\section{Due Diligence - Review Contracts Other than Your Own}

Every contracting party should review the contracts between the parties directly above them. In this case, a simple inquiry by Valard regarding the Bird and Langford contract would have revealed the existence of the bond. Knowing if this kind of security exists from the outset of an agreement is worth the extra time of reviewing the various project contracts.

\section{Meeting the Burden}

The question raised by the majority's decision is what an obligee should reasonably have done in the circumstances. ${ }^{63}$ The obligee need not inform every possible beneficiary, but instead must take reasonable steps to that end. ${ }^{64}$ This is fortunate, for as Justice Karakatsanis points out in her dissenting opinion, there may be third-party beneficiaries to whom the obligee owes a duty that will never even step foot on the job site. ${ }^{65}$

A prudent obligee could, where it has demanded the provision of an L\&M Bond as part of the contract, also require that the principal provide notice to each of its subcontractors or suppliers of the existence of the bond. An obligee could make the bond accessible online though a document management system, or post it physically on the project site. Similar requirements are articulated in the Alberta Public Works Act. ${ }^{66}$ However, whether any of this would be sufficient to satisfy the obligee's duty under the general laws of equity will have to be determined on a case-by-case basis. ${ }^{67}$

\section{TENDERING: BALANCING InTERESTS AND FAVOURING THE OWNER}

The Supreme Court of Canada has consistently held that the "integrity of the bidding system must be protected where under the law of contracts it is possible so to do." ${ }^{68}$ There 
are competing interests at play in the law of tendering. Owners and contractors soliciting bids want the most flexibility in selecting the winning bids, whereas the bidders want to be treated fairly and equally to avoid wasting resources while participating in the tendering process. Canadian courts have consistently stepped in to influence and create a legal playing field that balances these interests. The Supreme Court of Canada's historic decision in Ron Engineering, ${ }^{69}$ which established the Contract A / Contract B paradigm, is a prime example of the profound and lasting effect the judiciary can have on the financial interests of a particular industry or group of businesses.

That said, recent decisions might be tipping the scales in favour of those soliciting bids. Recently in Alberta and British Columbia, several decisions have addressed the appropriate exercise of an owner's discretion.

\section{A. The Alberta Court of Appeal's Decision IN EVEREST CONSTRUCTION}

The decision in Everest Construction Management Ltd. v. Strathmore (Town) ${ }^{70}$ confirms that owners have the right to select contractor bids based on considerations such as overall cost, scheduling preferences, relevant work experience, and prior interactions with the contractor. However, the call for tenders must expressly grant the owner such wide discretion and notify the bidders of the relevant assessment criteria. Further, an owner does not breach the requirement to treat all bids fairly and equally by awarding the contract based on these considerations.

\section{RELEVANT FACTORS IN BID SELECTION}

In Everest Construction, the bidder, Everest Construction Management Ltd. (Everest), submitted a bid for work on a reservoir and pump station project. The call for tenders, prepared by the Town of Strathmore (Strathmore), included an Invitation to Bid, Instructions to Bidders, and a Bid Form each containing terms that were relevant to the issues before the Court.

The two lowest bidders were Everest and Graham Construction Infrastructure (Graham). Everest had submitted a bid price of $\$ 6,440,433$ with a functional completion date of 21 March 2013 and an overall completion date of 15 May 2013. In its Bidder's Qualifications Form, Everest included only one completed project as relevant experience, though it subsequently informed Strathmore of four further projects it was working on. 
Graham's bid price, meanwhile, was higher by only $\$ 33,651$ and projected a functional completion date nearly four months earlier. In its Bidder's Qualifications Form, Graham listed six relevant projects. These projects were not completed by Graham, but by companies related by a common shareholder that operated under the Graham umbrella.

Strathmore awarded Graham the contract, relying on various factors, including:

(1) Graham's completion date complied with Strathmore's preferred completion date; (2) Everest's later completion date would result in increased costs to Strathmore likely to be greater than the difference between the Graham and Everest bid prices; (3) Graham could bring to bear more experience with similar projects; and (4) Everest did not provide a complete Equipment Suppliers list. ${ }^{71}$

Following Strathmore's decision to award Graham the contract, Everest commenced an action for breach of the implied duty to accept only compliant bids and to treat bidders fairly and equally, seeking damages in the range of $\$ 350,000$. The trial judge dismissed the action.

On appeal, Everest raised several arguments asserting that the trial judge erred in finding that Strathmore did not breach its implied duty of fairness in Contract A. Everest alleged that a duty of fairness was breached by Strathmore's evaluation of the bids on the basis of experience, scheduled completion, and additional costs, as well as by crediting Graham with the project experience of other corporate entities.

\section{ON APPEAL AND ADDRESSING THE IMPLIED DUTY OF FAIRNESS}

In finding that the trial judge made no reviewable error, the Alberta Court of Appeal held that "the fact that the tender documentation asked bidders to provide information about their experience and to state when they could complete the Project indicates that Strathmore intended to use that information to evaluate bids." 72

Everest contended that Strathmore intended to use the information as a "checklist" item. In other words, if the bidder had some relevant experience and was committed to a completion date, they were qualified. It made little sense to the Alberta Court of Appeal that an owner would hamstring itself in this way. ${ }^{73}$ The Court would not accept that an owner would be restricted from using the information as an evaluative criterion, as opposed to merely a threshold test. Further, the language in the tender documents unambiguously indicated that Strathmore would evaluate experience, asking that bidders "provide the following information in order that the Owner may judge [their] ability to fulfil the Contract requirement." 74 
On the question of whether Strathmore had failed to dutifully investigate Graham's experience, the Court noted, as a starting point, that an owner has no duty to investigate whether a bidder will be able to comply with its bid, but may investigate bids at its discretion. ${ }^{75}$ Importantly, the Court held that if Strathmore chose to investigate a bid, it was required to exercise its right to investigate bidders fairly. ${ }^{76}$

Everest's specific point of contention was that both the Everest and Graham bids were deficient on their faces with respect to project experience and that Strathmore had breached its duty of fairness by investigating Everest but not Graham. Instead of investigating Graham, Strathmore relied on assurances from Graham that it would have the experience and resources of the other Graham corporate entities. However, in its tender submittals, Graham did not explain how the personnel or experience of those companies would benefit the project.

On this point, the Court noted that there was persuasive authority from the New Brunswick and British Columbia Courts of Appeal supporting the proposition that an owner may rely on information it had already acquired through previous experience with the bidder when evaluating the bids. ${ }^{77}$ The Court held that "a rule requiring an owner to investigate information about a bidder that it already knows through past experience would be wasteful and offend common sense." relying on their general knowledge when evaluating bids might also introduce uncertainty into the tender process, and create more litigation risk." $" 79$

Consequently, as the request for tenders made it clear that Strathmore would use this information to evaluate bids, and as the town was under no obligation to investigate the projects Graham identified in its bid as having been completed by related companies, the Court dismissed this ground of appeal.

\section{THOUGHTS AND REFLECTIONS: OWNERS NOT OVERLY RESTRICTED}

Overall, Everest Construction indicates that owners have a broad discretion to select winning bids. However, owners and contractors soliciting bids should still be careful to employ appropriately worded privilege or discretion clauses to permit a more nuanced approach to bid selection, which does not require simply selecting the lowest bid. Overall cost, schedule, previous work experience, and prior knowledge or experience with the contractor are all valid considerations. The call for tenders should expressly notify any potential bidders of any additional criteria or significant considerations that may affect the owner's choice of contractor, in order to avoid disputes like the one in Everest Construction.

Ibid at para 30. See also Double N Earthmovers Ltd v Edmonton (City), 2007 SCC 3 at para 50 [Double $N$ Earthmovers]; Rankin Construction Inc v Ontario, 2014 ONCA 636 at paras 27-30; Cityscape Contracting Ltd v City of Edmonton, 2007 ABQB 161 at para 37.

Everest Construction, supra note 70 at para 31.

Cherubini Metal Works Limited v New Brunswick Power Corporation, 2008 NBCA 89; Continental Steel Ltd v Mierau Contractors Ltd, 2007 BCCA 292.

Everest Construction, supra note 70 at para 36.

Ibid. 
In the oil and gas context, this development may significantly influence a contractor's approach to project bids, given the scale, cost, and complexity of some infrastructure projects. Catering to the needs of the owner, as informed by the tender documents, means that proponents can choose to make certain aspects of their bids - such as schedule - more appealing, without necessarily having to worry about ensuring that their project costs are the lowest. Though certainly not encouraged, over-promising on these "soft" targets, like completion date, in a bid may also allow bidders to present a more appealing package without intending to actually deliver on their promise. Some bidders may take this approach to get their foot in the door, and deal with the inevitable delays later.

Additionally, some smaller contractors will be disadvantaged in that owners are permitted to consider not only a bidder's experience, but also the experience and resources of the bidder's affiliated entities. In this respect, larger proponents may be selected more often.

This case also engenders some sympathy for Valard's choice not to "rock the boat" as discussed above. If experience with a bidder is a legitimate criterion for which to overlook awarding a contract, bidders should be careful about maintaining healthy working relationships with prolific owners and contractors. This consideration is further exacerbated by the decision of the British Columbia Supreme Court in J. Cote \& Son Excavating Ltd. v. City of Burnaby, ${ }^{80}$ discussed below.

\section{B. The BRITISH COLumbia SuPREME COURT's DeCISION IN J. COTE \& SON EXCAVATING}

In J. Cote \& Son Excavating, the Court considered whether "reprisal" clauses in procurement policies or calls for tenders are unconstitutional or contrary to public policy. Ultimately, Justice Maisonville concluded that unless the complainant can show that it suffered undue hardship, neither the Canadian Charter of Rights and Freedoms, ${ }^{81}$ nor the Constitution Act, $1867^{82}$ render reprisal clauses invalid.

The plaintiff, J. Cote \& Son Excavating Ltd. (J. Cote), was a construction and excavation contractor that secured most of its work by way of bidding for municipal construction contracts with the City of Burnaby (Burnaby). While working on a project for Burnaby in 2013, a dispute arose between the parties over an allegedly concealed condition that resulted in the collapse of a structural retaining wall and, sadly, the death of one of J. Cote's employees.

Following the incident, J. Cote filed a notice of dispute as contemplated under the contract and the chosen referee decided in its favour. However, Burnaby declined to follow the referee's non-binding decision. Burnaby also refused to consent to arbitration. In December 
2013, J. Cote commenced an action in the British Columbia Supreme Court against Burnaby claiming that it was responsible for the retaining wall collapse.

Approximately two months after the start of the plaintiff's action, Burnaby added a new clause to its standard invitations to tender on municipal works. This "reprisal clause" stated:

\begin{abstract}
Tenders will not be accepted by the City of Burnaby (the "Owner") from any person, corporation, or other legal entity (the "Party") if the Party, or any officer or director of a corporate Party, is, or has been within a period of two years prior to the tender closing date, engaged either directly or indirectly through another corporation or legal entity in a legal proceeding initiated in any court against the Owner in relation to any contract with, or works or services provided to, the Owner; and any such Party is not eligible to submit a tender. $^{83}$
\end{abstract}

This provision barred bids from proponents that had engaged in litigation against Burnaby within the previous two years, which therefore precluded J. Cote from bidding on further work.

\title{
1. J. Cote's Plea: SeEking Refuge Under the Protection OF THE CHARTER OR THE CONSTITUTION
}

Following the inclusion of the reprisal clause in Burnaby's call for tenders, J. Cote applied for a summary trial seeking a declaration that the reprisal clause was invalid.

The plaintiff argued that the clause infringed on its rights under the Charter by imposing a limit on its right of access to the courts. The clause imposed this restriction by dissuading J. Cote, and other contractors, from litigating to avoid missing business opportunities. To that end, the plaintiff submitted evidence that it had lost business because of the clause, citing nine contracts tendered by Burnaby during the time it was barred from bidding. J. Cote also calculated that "it had lost about 17 percent of its normal business solely because it took the City to court." ${ }^{" 14}$ The plaintiff also argued that the clause was inconsistent with the rule of law, that it offended section 96 of the Constitution, and that it was contrary to public policy.

In response, the Attorney General argued that the common law did not create a freestanding right of access to justice in the circumstances. To seek a remedy under the Charter or the Constitution requires the breach of a specific right or freedom. Though case law supports that there is a constitutional right of access to the courts pursuant to section 96 of the Constitution, that right is subject to permissible limits. ${ }^{85}$ The Attorney General accordingly argued that J. Cote would have to meet the high threshold of establishing that it suffered undue hardship in accessing the courts. ${ }^{86}$ The Attorney General also argued that

Ibid at para 74

Trial Lawyers Association of British Columbia v British Columbia (Attorney General), 2014 SCC 59 at paras $45-46$. 
a limit on access to justice imposed by contract is not constitutionally protected in the same manner as legislation or a bylaw enacted by Burnaby.

The Court found, first, that section 24 of the Charter is not a remedy for unconstitutional acts in general. The plaintiff relied on several Supreme Court decisions in support of the proposition that access to justice is a fundamental constitutional right. However, citing the plaintiff's own authority, British Columbia (Attorney General) v. Christie, ${ }^{87}$ the Court pointed to the fact that,

[t]he right affirmed in B.C.G.E.U. is not absolute. The legislature has the power to pass laws in relation to the administration of justice in the province under s. 92(14) of the Constitution Act, 1867. This implies the power of the province to impose at least some conditions on how and when people have a right to access the courts. Therefore B.C.G.E.U. cannot stand for the proposition that every limit on access to the courts is automatically unconstitutional. ${ }^{88}$

Further, the plaintiff "must be able to point to a breach of a specific right or freedom set out and guaranteed in the Charter in order for a remedy to be available." ${ }^{\circ 9}$ As the Charter gives no general right of access to the courts for the resolution of civil disputes, there is no remedy under the Charter for an impaired right of access. Because J. Cote's argument was not anchored in a particular section, the Court found that there was no constitutional remedy available pursuant to either section 24(1) of the Charter or section 52(1) of the Constitution Act, $1982 .^{90}$

In addressing whether the plaintiff met the burden of undue hardship, Justice Mainsonville confirmed that the complainant must satisfy a high threshold..$^{91}$ In this case, the plaintiff argued that it met this threshold, given the high percentage of its work that it claimed came from Burnaby. The Court, however, held that the fact that a contractor might choose to avoid pursuing its rights in court as a result of a reprisal clause was not sufficient on its own to establish undue hardship. The plaintiff had failed to furnish sufficient evidence that it had lost enough business to amount to undue hardship. The Attorney General argued that the plaintiffs evidence was speculative as it was based on past work allocation without guarantee of future contract awards. In the end, the Court was not satisfied that, based on the evidence presented, the plaintiff had met the burden.

On the public policy issue, the plaintiff brought to the Court's attention the decision of Justice Shabbits in Sound Contracting v. City of Nanaimo. ${ }^{92}$ In that case, the Nanaimo City Council had passed a resolution excluding bids under its public tender policy from any company engaged in legal action related to work for the City, just as in the case at bar. The Court in Sound dismissed the action, finding that the tender policy fell within the City's 
power under the former British Columbia Municipal Act, ${ }^{93}$ to engage in commercial, industrial, or business undertakings. Justice Shabbits had held that he was satisfied that the tendering policies, and the underlying resolution passed by City Council, were implemented for valid commercial or business purposes; namely that the City had solid business reasons for why it should not be entertaining bids from firms that had active lawsuits against the City for similar work.

J. Cote brought this case to the attention of the Court to argue that it was only tangentially relevant, and that it was distinguishable from the case at bar. However, the Court appeared to agree with the reasoning in Sound. It found that, in the absence of bad faith, clauses that bar bids from contractors engaged in litigation serve a commercial purpose and are valid. Discouraging litigation is not the same thing as preventing it, and if the two were to be treated the same, the undue hardship analysis would be undermined. The plaintiffs were free not to submit bids where tender documents contained such clauses if they did not wish to be subject to such clauses. On this basis, the Court found that the impugned clause was valid and not contrary to public policy. The action was dismissed.

\section{ThOUghts And ReFlections: A High THRESHOLd FOR BIDDERS}

This case stands for the proposition that, absent evidence of undue hardship, reprisal clauses that penalize proponents who litigate against the owner are valid and do not violate any rights of the bidder, constitutional or otherwise. ${ }^{94}$

In this context, it seems that bidders for oil and gas projects have another reason to carefully consider the impact that legal proceedings might have on their future business opportunities. Whether explicitly stated in the tender documents, or treated as "past experience" as in Everest Construction, this evolving landscape is becoming increasingly treacherous for bidders. Conversely, project owners should consider reprisal clauses as a means to deter litigation and avoid being required to select a bidder with whom they have had trouble in the past.

That being said, it would seem that bidders who receive the majority of their work from one owner will have an easier time challenging the validity of the reprisal clause. Losing all, or most, of one's work would create a serious risk of undue hardship to a bidder. Though untested in the courts, this may lead to inconsistent results, depending on the varied nature of a proponent's portfolio. This may also encourage bidders to create individual corporate entities for bidding exclusively on large owner projects where the right to bring litigation may be necessary for dispute resolution.

94 Following the initial drafting and presentation of this article, the British Columiba Court of Appeal affirmed Justice Maisonville's trial level decision in J Cote \& Son Excavating Ltd v Burnaby (City), 2019 BCCA 168. In short, the Court of Appeal held that, "[t] the only path to a constitutional remedy for a denial of access to the civil superior courts is through s. 96 of the Constitution Act, 1867, which is not engaged or infringed in this case. The appellant was not denied access to the courts. Even if s. 96 were engaged, the appellant failed to prove the Clause caused it undue hardship" (ibid at para 3). 
The evidence required to prove undue hardship remains uncertain. J. Cote's president deposed "that over the last 15 years, approximately 70 percent of J. Cote's work" came from competitive bidding with local government entities. Of that work, 25 percent was for Burnaby. ${ }^{95}$ Despite this, the Court held that it had insufficient evidence to permit a finding of undue hardship. ${ }^{96}$ This case, therefore, provides little guidance with respect to what evidence might have demonstrated undue hardship in the circumstances.

Importantly, a proponent seeking relief from a private corporation's call for tenders is not likely to find comfort in Charter remedies. Bidders and owners should be aware that any limits on reprisal clauses that this decision might have imposed are unlikely to apply in the private sector. The Court here, nonetheless, still draws the overarching connection between reprisal clauses and bad faith, which may apply to private contracting and tendering in the post Bhasin v. Hrynew ${ }^{97}$ world.

To be excluded from tendering a bid as a result of exercising legitimate legal rights seems contrary to the rule of law. Unfortunately, constitutional rights provide little relief. In response, proponents may wish to modify their corporate structures to respond accordingly and bid on projects with unrelated entities. However, where experience is also a consideration, as in Everest Construction discussed above, this may not be an option.

\section{The British Columbia Court of Appeal's DECISION IN MAGLIO}

Though the case law may appear to be shifting in favour of the owner's interests, in Maglio Installations Ltd. v. Castlegar (City) ${ }^{98}$ the British Columbia Court of Appeal reemphasized that courts must apply a stringent analysis to issues relating to the tendering process and must seek to preserve certainty and fairness to compliant bidders wherever possible. Specifically in Maglio, the Court held that while an owner may include a right to waive defects in its invitations to tender, that right does not allow the owner to waive material defects such as a bidder's failure to include a preliminary construction schedule (PCS) in its bid.

\section{THE TRIAL DECISION}

This dispute arose out of the City of Castlegar's (Castlegar) invitation to tender bids for the construction of a swimming facility. The plaintiff submitted a bid that was fully compliant with the defendant's invitation to tender, whereas the successful bidder did not include a PCS as required by the tender documents. 
The call for tenders contained a "discretion clause" written as follows:

The City reserves the right to reject any or all tenders, to waive defects in any bid or tender documents and to accept any tender or offer which it may consider to be in the best interest of the City. ${ }^{99}$

The plaintiff sued Castlegar and sought summary judgment for breach of contract, alleging that the defendant had breached its duty of fairness arising from Contract A by awarding the project to a bid containing a material defect.

At trial, the parties agreed that when Maglio Installations Ltd. (Maglio Ltd.) submitted its materially compliant bid, it formed Contract A with Castlegar. It was further agreed that a discretion clause only permits an owner to waive minor irregularities or non-material defects. ${ }^{100}$

Castlegar argued, however, that the PCS, or lack thereof, in the winning bid was immaterial because there were no firm milestone dates set until after the bidding period had concluded. Thus, any successful bidder would have had to amend the PCS anyway. Further, Castlegar submitted that the information contained elsewhere in the tender documents, and in particular the information provided by the successful bidder, rendered the PCS redundant. Ultimately, the commitment to meet the milestone dates satisfied and surpassed any purpose that the PCS would otherwise serve. On this basis, Castlegar exercised its discretion to forgive what was, in its opinion, a non-material defect and accept the bid.

The trial judge disagreed, and held that the non-compliance of the successful bidder was material because:

(1) the preliminary schedule was "front and center" in the tender documents; ${ }^{101}$

(2) the tender documents expressly stated that time was of the essence in completing the project; ${ }^{102}$ and

(3) the schedule would have been a significant factor in Castlegar's deliberations when it was choosing bids because the project timelines were subject to a regulatory window and had to accommodate the Environmental Management Plan prepared by Golder Associates. ${ }^{103}$

The trial judge granted judgment to the plaintiff for breach of contract. Castlegar then challenged the order before the British Columbia Court of Appeal. 


\section{The COURT OF APPEAl DeCiSiOn: MATERIALITy OF PRELIMINARY CONSTRUCTION SCHEDUles}

On appeal, the main issue before the Court was whether, considered in light of the appropriate standard of review, the judge erred in his assessment of the materiality of the PCS. Castlegar argued, among other things, that the trial judge erred by not properly considering the context of the uncertain milestone dates and by overemphasizing the importance of the "time is of the essence" clause. Castlegar maintained, also, that the judge failed to recognize that the regulatory window was unknown to tenderers at the time of closing, which left a "critical deficiency in the information required to complete the PCS Table,' depriving the PCS of utility at the time of closing." 104

The respondent plaintiff, Maglio Ltd., pointed out that Castlegar did not allege that the judge made a palpable and overriding error, and that the evidence supported the judge's conclusion that the successful bid was materially non-compliant with the invitation to tender. Further, Maglio Ltd. submitted that the PCS demonstrated that bidders had turned their minds to a timeline for the major phases of construction. In respect of the "time is of the essence" clause, Maglio Ltd. argued the inclusion of the clauses indicating completion of construction tasks in the requisite timeline rendered the clause fundamental to the project.

The Court first determined that because the issue was one of mixed fact and law, rather than a question of law to which it could apply the standard of correctness, it would overturn the trial judge's ruling only if it found palpable and overriding error. Next, on the question of materiality, the Court referred to the two-step test found in Graham Industrial to determine whether a defect in a bid is material. ${ }^{105}$

Graham Industrial involved a situation where a contractor, Graham, had submitted an underestimated bid. When Graham sought to withdraw the bid, on the basis that it contained a material mistake and was incapable of acceptance, the Greater Vancouver Water District (the District) refused and awarded the project to Graham. The instructions had stated, as they had in Maglio, that the District had the sole discretion to waive any defect in a tender and accept the tender. The judge found that the clause was subject to objective scrutiny, and that Graham's tender was deficient and could not be validly accepted.

The Court in Maglio agreed with and adopted the test from Graham Industrial, setting out that a defect in a construction contract bid is material where:

(1) the defect has to do with "an important or essential requirement of the tender documents"; ${ }^{106}$ and 
(2) "there is a substantial likelihood that the omission would have been significant in the deliberations of the owner in deciding which bid to select."107

Regarding the first element of the test, the Court in Graham Industrial found that the materiality of a defect must be assessed on an objective reading of the tender documents at the time they were submitted. ${ }^{108}$

The Court in Maglio consequently noted that nearly an entire page of the call for bids was devoted to this requirement of a PCS and the tendering documents as a whole "made it clear that timing would be an essential aspect of Contract B." ${ }^{109}$ In this respect, the Court reiterated its words in True Construction Ltd. v. Kamloops (City):

[W]here the tendering documents on their face require the information in question and there is some indication in the documents that the information is material, prima facie, the information is an important or essential requirement of the tender. No further evidence is needed to support that result. ${ }^{110}$

On the second element of the Graham Industrial test, the Court in Maglio declined to place any importance on the subjective reasoning of the bid evaluator, choosing rather to look at whether the requirement in question would be objectively useful to a reasonable bid evaluator. The City had argued that a change to the Graham Industrial test was appropriate in the circumstances to give effect to the commercial reality and wishes of the party seeking bids. However, the Court found that this approach would substantially increase the discretion of those calling for bids to accept non-compliant bids.

In assessing whether the required information would be objectively useful, the Court held that the question would be satisfied so long as the defect was related to a requirement that is "neither redundant nor useless." 111 As the preliminary schedule provided information on how and when the bidders would complete the work - obviously pertinent information the schedule was material despite the uncertain milestone dates. There was no palpable and overriding error in the trial judge's conclusion; therefore, the appeal was dismissed.

\section{Thoughts ANd Reflections: Some Lines ARE Still Clear}

A bid evaluator must take care in seeking to rely on discretion clauses. However, while Maglio vindicates a bidder's right to be treated fairly in the tendering process, it does nothing to change the fact that bidders may, for example, include a PCS without any intention of living up to it. The fact that the schedule in this case was "preliminary" speaks to the uncertainty that usually surrounds schedules in the very early phases of a construction project's life. One must therefore sympathize with Castlegar's position that failing to provide a PCS was a non-material defect. 
In part, this decision came down to the standard of review precluding an appellate court from "reweigh[ing] the evidence considered by the judge and reach[ing] a different conclusion," 112 but more than anything it showed that bidders must tread a careful line. By providing a PCS, the bidder may be held accountable to it; but without sufficient information providing an accurate PCS might be impossible. In this case, Maglio Ltd. provided the PCS, while the winning bidder did not. Whether Maglio Ltd. could have, at the end of the day, delivered on that PCS and whether they would instead be defending a claim for delay later on, we will never know.

\section{SUMMARY}

Overall, the above cases indicate a shift toward greater freedom of contract, specifically with respect to an owner's right to create flexibility in bid selection. These cases, particularly Everest Construction and J Cote \& Son Excavating, give owners significant power to dictate which parties are entitled to bid and which bids they select. So long as tender documents are properly drafted, and basic principles of fairness are observed, owners are not always obliged to choose the lowest bid, or even, where omissions do not rise to the level of materiality, the "most compliant" bid.

In the oil and gas context, the above authorities may create challenges for bidding contractors, particularly smaller operators (as suggested by Everest Construction). The $J$ Cote \& Son Excavating decision is particularly significant, as the size and scope of oil and gas infrastructure projects often result in legal disputes, and there are a limited number of owners with whom potential proponents can contract. The result may be a significant chilling effect on litigation, as contractors fear foregoing the chance to bid for future projects. Where such contractors have a strong cause of action, they may be foregoing a large costs or damages award to which they could be entitled. It will be a fine balancing act to gauge the best strategic path.

\section{Liens on OIL And Gas Projects: EVERYTHING BUT THE KITCHEN SINK}

The $B L A$, as it stands, may not effectively serve the needs of the oil and gas industry. The provisions therein, and the nature of the land registration system in Alberta, have created convoluted registration processes in certain circumstances. Registering a lien against the right interest, with the appropriate land titles office, in the right amount of time are only a few examples of the kinds of challenges a lien claimant faces. These situations must be navigated carefully, as some errors in registration can be fatal to a right or claim under the $B L A$. 
In order to compensate for this potentially confusing system, Alberta courts expend great energy in finding ways to achieve what they perceive to be just results. For example, registering a lien on the wrong land may not extinguish the claimant's right if the land to which the lien erroneously attaches is next to the correct plot. Further, where the BLA leaves room for interpretation, Alberta judges have taken a broad approach to prescribing meaning. This has captured many activities including, for example, demobilization as the proper substance of a lien claim.

All parties involved in construction on oil and gas projects, whether or not it is obvious that such work is related to the recovery of a mineral, should take careful note that the BLA can be a flexible and inclusive instrument.

\section{A. The International Brotherhood AT THE QueEN's BenCH}

In International Brotherhood of Electrical Workers, Local 424 v. Imperial Oil Resources Ventures Limited, ${ }^{113}$ the International Brotherhood of Electrical Workers, Local 424 (IBEW) registered a builders' lien on behalf of several of its electrician members in connection with work performed on the Kearl Oil Sands Project (the Kearl Project). The electricians, through IBEW, had entered into a Special Project Needs Agreement (the SPNA) with the defendants, Imperial Oil Resources Ventures Limited and Exxon Mobil Canada Properties (Imperial). The SPNA "expressly provided that it "does not apply to work which is not "construction" work and does not apply to exploration or related works at or near the project." "114

According to Master Robertson, where a lien in connection with the construction of a building rather than recovery of a mineral is registered only against the surface interest, it is a lien under section 6(1) of the BLA and ought to be registered with the Alberta Land Titles Office rather than the Minister of Energy. In further discussion, Master Robertson left open the possibility for a broad interpretation of what constitutes "work" in connection with the recovery of a mineral. Accordingly, the lien claim in this case might have, though it was unnecessary to decide the issue, been capable of attaching to the whole of the project, including both the surface and mineral interests.

\section{THE STATUTORY FRAMEWORK}

Section 6(1) of the BLA is the general provision that creates a right to lien for work or materials provided "on or in respect of an improvement." 115 Section 6(2), meanwhile, specifically addresses liens on mineral recovery jobs. ${ }^{116}$ It contains a broad right to register liens and has the potential to allow liens to attach to the interests of parties other than the party who requested the work. 
In particular, when work or materials are provided preparatory to, in connection with, or as part of an abandonment operation for the recovery of a mineral, the lien attaches to all estates and interests in the mineral concerned, other than the fee simple interest in those mines and minerals. However, if the person who requested the work also owns the fee simple interest in the mines and minerals, then a section 6(2) lien will also attach to that interest. In those circumstances, the remaining interest of the fee simple owner in the rest of the land remains unencumbered. In Alberta, the fee simple owner of mineral interests is usually, but not always, the Crown.

Section $6(2)$ of the $B L A$ is, in its entirety, written as follows:

(2) When work is done or materials are furnished

(a) preparatory to,

(b) in connection with, or

(c) for an abandonment operation in connection with,

the recovery of a mineral, then, notwithstanding that a person holding a particular estate or interest in the mineral concerned has not requested the work to be done or the material to be furnished, the lien given by subsection (1) attaches to all estates and interests in the mineral concerned, other than the estate in fee simple in the mines and minerals, unless the person holding the estate in fee simple in the mines and minerals has expressly requested the work or the furnishing of material, in which case the lien also attaches to the estate in fee simple in the mines and minerals but not to that person's estate, if any, in the rest of the land. ${ }^{117}$

In International Brotherhood, Master Robertson notes that the expanded consequence of section 6(2) is different from other liens that are not related to the recovery of a mineral. A non-mineral lien arises when the work is done or materials are furnished "for an owner, contractor or subcontractor." "The resulting lien in that circumstance attaches only to "the estate or interest of the owner in the land." 119 A section 6(2) lien, however, attaches to all of the estates and interest in the mineral, excepting the estate in fee simple in the mines and minerals.

As Master Robertson explains, sections 6(1) and (2) are not contradictory. Rather, each may serve to grant a right to lien potentially different interests. The interest encumbered depends on whether the work or materials are in relation to the recovery of a mineral. The distinction does, however, complicate matters for construction projects in the energy industry. Master Robertson expressly acknowledges that the $B L A$ is not well tailored to heavy oil extraction projects. ${ }^{120}$

Ibid.

Ibid, s 6(1).

Ibid.

International Brotherhood, supra note 113 at para 31. 
Traditionally, liens on mineral recovery jobs were registered with the Minister of Energy. The process of recovering minerals such as natural gas and oil used to, in the simplest of terms, involve drilling a well and later installing a pump jack. However, the BLA seems not to have properly adapted to reflect the fact that a significant portion of minerals are now extracted by heavy oil projects. Operating a heavy oil project is, in Master Robertson's own words, "no small undertaking." 21 It involves the construction of temporary and permanent buildings, the operation of heavy equipment, and the use of large parcels of land. Hence, the peripheral and expanded processes of recovering minerals on a heavy oil project appears not to have been captured by the $B L A$.

For example, in this case, electricians did the work. Master Robertson found that the building on which the electricians had worked, was only incidentally "in connection with" the recovery of minerals. The building itself was not likely directly involved with the recovery of the minerals, nor could the wiring of the building be generally considered to be "in connection with" such recovery. In fact, the SPNA specifically excluded the work from applying to the exploration or related works at or near the project.

Master Robertson found, instead, that the work was done in connection with the construction of an improvement as contemplated by section 6(1). It was therefore a section 6(1) lien. Interestingly, however, Master Robertson left open the possibility that "the lien may nonetheless have attached to the whole project, including the mineral interest."122 Leaving open this possibility appears to have been a result of the contemporaneous decision of the Alberta Court of Queen's Bench in Trotter and Morton Building Technologies Inc. v. Stealth Acoustical \& Emission Control Inc. (Stealth Energy Services), ${ }^{123}$ discussed below, of which Master Robertson was not aware until argument. ${ }^{124}$

\section{LIENS AGAINST UNPATENTED LAND}

Master Robertson also addressed that the lien was registered against unpatented land. ${ }^{125}$ Thus, the electricians could not register their lien against the fee simple interest since it resided with the Crown, whose land is generally immune to liens. ${ }^{126}$ Further, Imperial's surface lease had not been registered with the Registrar of Land Titles. The Alberta Energy Regulator issued a "mineral surface lease" to provide Imperial with the legal right to occupy and use the lands for the purpose of an oil sands mine. ${ }^{127}$ Notably, the mineral surface lease

\footnotetext{
$121 \quad$ Ibid.

122 Ibid at para 45.

1232017 ABQB 262 [Trotter and Morton].

124 International Brotherhood, supra note 113 at para 111.

125 Ibid at para 22:
}

Sometimes land is not "patented", meaning that there has been no certificate of title issued by the provincial Crown. In those circumstances, when a worker or a supplier wants to register a lien against the unpatented land, section 35(4) directs the Registrar to "make a record of the lien in a book or in any other manner that the Registrar considers advisable." Majesty or Her Majesty's rights or prerogatives in any manner, unless the enactment expressly states that it binds Her Majesty." 
was distinct from the oil sands lease; the former did not entitle Imperial "to use, drill for, work, or recover minerals." 128

Master Robertson noted that this system of registration for mineral projects on unpatented land underscores why the $B L A$ is not well structured for work done in the energy industry. The Minister of Energy registers interests that perhaps would better be registered at the Land Titles Office, but there is no title against which to register them.

As a result, Imperial argued that everything related to the oil sands project was to be registered with the Minister of Energy, including builders' liens against surface leases. Imperial further asserted that because IBEW registered its lien with the Registrar of Land Titles, and not the Minister of Energy, it was ineffective and should be struck.

In determining whether the lien could properly attach to the project's surface rights, Master Robertson made several observations:

1. The corporations that appeared to have retained the trades under the Special Project Needs Agreement apparently [did] not hold an oil sands lease. They apparently only [had] a surface lease.

2. The disclaimer that appears on the [Minister of Energy's] Public Land Standing Report [which discloses any registered surface interest and shows any surface leasehold interest that Imperial might have] specifically tells readers to check the Land Titles Office for builders' liens.

3. The "Certified Copy of Nonpatent Sheet" on which the Registrar [of Land Titles] recorded the lien by the electricians records ... 18 liens registered against the property by a variety of ... suppliers or subcontractors. $^{129}$

Master Robertson also observed that, when related to energy projects, builders' liens are routinely registered against both the surface interest and mineral rights. In his view, registration in both places reflects the fact that there are two distinct interests, and that perhaps lien claims may attach to both.

Here, however, the work done on the surface benefited the surface interest alone, and the lien therefore attached only to that interest. The Court noted that where other contractors or suppliers may have provided materials or work that benefited the mineral interest, it would have been quite proper to register their liens with the Minister of Energy, as is expressly provided in section 36 of the $B L A$. Further, where work or materials might benefit both the surface interest and the mineral interest, the lien would attach to both. It would be appropriate for such a party to register both at the Land Titles Office and with the Minister of Energy. 
There was no disagreement that the electricians had a proper lien claim. Rather, the arguments centered on whether the right to lien was lost because it was: (1) registered only at the Land Titles Office, or (2) registered without specifically saying it attached to the leasehold interest of Imperial. In rendering his decision on these points, Master Robertson cited Norson Construction Ltd. v. Clear Skies Heating \& Air Conditioning Ltd., wherein Master Prowse did not invalidate a lien because the claimant had named the wrong owner. ${ }^{130}$ In Norson, Master Prowse relied on the Alberta Court of Appeal's decision in Canbar West Projects Ltd. v. Sure Shot Sandblasting \& Painting Ltd. for the proposition that:

Specifically, courts are required to adopt a strict interpretation in determining whether a lien claimant is entitled to a lien, and a liberal approach with respect to those to whom the statute applies ... Builders' liens are business oriented statutes with practical, as opposed to formulistic, goals; their overall intent is to ensure that "the land that receives the benefit shall bear the burden."131

Thus, in Norson, an error in listing a different party as the owner in the Statement of Lien did not cause it to fall under the strict interpretation doctrine. In his decision, Master Prowse noted that the "lien already existed. It was not created when the lien form was filed at Land Titles." 132 In light of the Court's decision in Canbar West, and its subsequent application in Norson, Master Robertson concluded that although the form of lien did not specify expressly that it was attaching to Imperial's leasehold interest, the lien remained valid and had not been lost.

\section{REGISTRATION OF LIENS IN THE}

\section{ALBERTA ENERGY INDUSTRY: SMOKY RIVER COAL}

With respect to whether the lien was lost on account of having been registered only with the Land Titles Office, Master Robertson referred to Justice LoVecchio's decision in Re Smoky River Coal Limited. ${ }^{133}$ In Smoky River Coal, the Alberta Court of Queen's Bench considered a lien relating to work on a mineral extraction site and determined that it is possible to have a lien that attaches to both the surface interest and the mineral interest. ${ }^{134}$ Justice LoVecchio discussed what is now BLA section 6(2), noting that it says only that a lien can exist on the mineral title alone, but that it does not preclude the existence of a simultaneous lien on a surface interest. Citing Smoky River Coal with approval, Master Robertson concluded that, "even if the work that they did was solely related to the mineral recovery, the Lienholders are entitled to a lien attaching to ... corresponding surface interests." 135 
In Smoky River Coal, the Court was dealing with issues of priority as between lien claimants and lending security instruments. After concluding the mineral interest liens are to be recorded with the Minister of Energy, but that the surface interest liens on unpatented lands were to be registered with the Registrar of Land Titles, Justice LoVecchio stated that " $[\mathrm{t}]$ he legislation is inconsistent in that it provides for registering liens against unpatented land at Land Titles on the non-patent sheets but does not provide for registering competing mortgages." ${ }^{\text {"136 }}$ He then resolved the inconsistency of the Smoky River Coal decision, stating:

It is the practice in Alberta to register security taken against surface leases of unpatented Crown land in the Department of Energy as these are incidental to the mineral leases. Since the surface leases depend upon the granting and good standing of the underlying mineral lease for their very existence, it only makes sense that security interests against them should be registered in the Department of Energy along with claims on the mineral interest itself. ${ }^{137}$

Therefore, the registration with the Minister of Energy resolves priority disputes. Mortgages and surface leases cannot be registered at the Land Titles Office if the land is unpatented, so registering with the Minister of Energy becomes the default system for determining priorities. However, surface-interest builders' liens that are registered at the Land Titles office are valid. Master Robertson found this to be a correct interpretation of the $B L A$, as it reflected both the practice for registering liens in Alberta as well as the understanding of the Minister of Energy on this process as reflected in the disclaimer attached to the Public Land Standing Report. ${ }^{138}$

\section{THOUGHTS AND REFLECTIONS}

Simply put, International Brotherhood stands for the proposition that where a lien "in connection with" the construction of a building rather than recovery of a mineral is registered only against the surface interest, it is a section 6(1) lien and ought to be registered with the Registrar of Land Titles rather than the Minister of Energy. This appears to be the case even where the land is unpatented. However, Master Robertson only became aware of other contemporaneous decisions after hearing argument. Accordingly, and as discussed in greater detail below, this meant that the electricians' lien may have still attached to the whole of the project. This expansion of the interpretation of what constitutes work "in connection with" the recovery of a mineral is an important point both for owners and subcontractors working on oil and gas projects.

Smoky River Coal, ibid at para 60.

Ibid at para 64 [footnotes omitted].

See International Brotherhood, supra note 113 at para 66 [emphasis in original], where Master Robertson wrote,

[t]he Public Land Standing Report expressly provides at the end, under the heading "disclaimer", the following, (which is printed all in capital letters, although I will not reproduce it in that form here): “This report does not show caveats, builders' liens, or other instruments, if any, registered at Land Titles office in respect of any lands or interests therein. Persons are advised to also examine records of Land Titles office to ascertain whether other instruments that may concern the lands or interests therein have been registered." 
In any event, a prudent party will always ensure that their lien is registered with both the Land Titles Office and the Minister of Energy, particularly if there is some uncertainty as to whether the work they are doing is "in connection" with the recovery of a mineral. The harm of registering a lien at the wrong registry is minimal compared to the harm that results from failing to register a lien in time at all.

\section{B. Trotter AND Morton AT THE QUEEN's BenCH}

Trotter and Morton was a combined action concerning the validity of two liens filed under the BLA. One lien was registered by Trotter and Morton Building Technologies Inc. (Trotter), while the other was registered by Hamil Contracting Corp. (Hamil). Trotter and Hamil were subcontractors to Stealth Acoustical \& Emission Control Inc. (Stealth). Stealth, in turn, had a contract with Canadian Natural Resources Limited (CNRL), who hired Stealth under an "Offsite Fabrication Agreement" to build four pumphouse buildings at Stealth's Calgary facility for delivery and use, ultimately, on CNRL's Horizon oilsands project. Stealth later went into bankruptcy and receivership, leaving Trotter and Hamil unpaid.

The key issue in this case was whether the pumphouses constituted "improvements" as defined by the BLA. In order for their liens to be valid, Trotter and Hamil had to show that the work and materials they provided related to such improvements.

\section{PUMPHOUSES QUALIFIED AS AN IMPROVEMENT}

The $B L A$ defines an improvement as:

[A]nything constructed, erected, built, placed, dug or drilled, or intended to be constructed, erected, built, placed, dug or drilled, on or in land except a thing that is neither affixed to the land nor intended to be or become part of the land. ${ }^{139}$

The subject pumphouses were large, heavy buildings. They were designed to ultimately be affixed to the land and intended to be fully integrated into the larger Horizon oilsands project. Master Prowse held that, "[w]ithout more, they would appear to be an 'improvement' to the Horizon site." 140 In that regard, the Court also took note of the fact that the pumphouses were designed so that, at a later point, they could be detached from the land and moved without damaging them. This was part of their intended purpose. Accordingly, CNRL argued that the liens were invalid because the pumphouse buildings were neither affixed to, nor intended to become part of the land, permanently and were therefore not an "improvement" to the Horizon project.

Master Prowse undertook a detailed analysis of the nature and purpose of the pumphouses. This included considering their size and weight, their role in tailings management, as well as the likelihood that they would ever be moved from the Horizon project site. He noted that 
the pumphouse buildings were to be transported by CNRL from Stealth's Calgary yard to the Horizon site and placed at known and specifically designated locations. Once delivered, the pumphouse buildings were to be integrated into the larger Horizon MFT Buffer Facility, where they would pump and recirculate bitumen tailings to and from tailings ponds. Master Prowse noted that the pumphouse buildings were to be an integral part of the MFT Buffer Facility, and that the Facility could not function as designed without the pumphouse buildings in operation. Further, Master Prowse noted that the entire Facility, including the pumphouse buildings, was designed to be fully integrated into the larger Horizon project and would be operated and controlled remotely from Horizon's main control centre.

In his decision, Master Prowse considered previous case law questioning whether similar structures had constituted "improvements." Counsel for CNRL submitted that the facts of the case were similar to those in Re Gauntlet Energy Corp. ${ }^{141}$ In that case, Justice Romaine held that the supplier of sour gas separator packages to a number of well sites were not entitled to a lien as the separator packages in question did not constitute an improvement under the $B L A$. In particular, she stated:

\footnotetext{
[S]eparator packages have been affixed to the land in a manner that allows them to operate properly by being mounted to skids that were welded to metal piles driven in the muskeg. However, they can be, and were moved, from well site to well site. They were never used at the first site to which they were delivered.
}

It is clear from this evidence that the separator packages were not intended to be or to become part of the land in question.

I find that they are not improvements as defined in the Act and, therefore, their supply is not lienable work. ${ }^{142}$

However, Master Prowse found that Gauntlet was distinguishable for a number of reasons. He noted that Gauntlet did not provide a physical description of the separator packages, nor their dimensions or weight. From a picture obtained from the pleadings file, it seemed that the Gauntlet separator packages were much smaller than the pumphouse buildings in question here, and were designed to be moved from well site to well site rather than to other contiguous lands on the same project. Most importantly, drilling at the initial sites in Gauntlet did not result in producing wells, such that the separator packages were never installed and instead were moved to new well sites. In other words, the structures were never installed on the lands subject to the liens.

On this basis, Master Prowse concluded that the pumphouse buildings constructed under the Stealth contract were "improvements" under the BLA. The only factor that may have favoured a different conclusion was the contingency that the pumphouses would be moved some time in the future. In that regard, however, it was likely that they would be moved to another place on the liened Horizon project. In the Court's opinion, that possibility was a persuasive reason to allow the liens. 


\section{TrotTER AND HAMIL's Alternative ARgument}

Interestingly, Trotter and Hamil also advanced an alternative argument that if the pumphouses were not found to be improvements themselves, then the Horizon oilsands project as a whole was the improvement to which their liens attached. Master Prowse accepted this argument. ${ }^{143}$

The argument relied on the specific provisions, found in section 6(2) of the $B L A$, under which the pumphouses were said to be "materials ... furnished ... in connection with ... the recovery of a mineral." 144 Master Prowse noted that the principle that an entire oilsands plant could be considered an "improvement" was supported in Grey Owl Engineering Ltd. v. Propak Systems Ltd. ${ }^{145}$

In Grey Owl, the Onion Lake Cree Nation had leased its mineral rights in a parcel of land to BlackPearl Resources Inc. (BlackPearl). BlackPearl contracted with Propak Systems Ltd. (Propak) for engineering, procurement, and fabrication services connected to a modular oil extraction system that was to be provided by Propak for use on BlackPearl's leased land. Propak entered into a subcontract with Advanced Metal Concepts and Fabrication Ltd. (AMCF) for the construction of three storage tanks to be used on the land as part of the modular oil extraction facility. In turn, AMCF entered into a subcontract with Grey Owl Engineering Ltd. (Grey Owl) to provide engineering design services relating to those storage tanks. Grey Owl, the lien claimant, filed its lien against the mineral parcel.

In the lower Court, Propak successfully argued that the "improvement" to be considered was the storage tanks, which in Propak's submission were not sufficiently affixed to the land to meet the definition of improvement in the Saskatchewan legislation. The Saskatchewan Court of Appeal summarized the decision of the lower Court as follows:

In short, it is a mistake to begin and end the inquiry with whether the storage tanks are the improvement. The issue is whether Grey Owl provided "services" "on or in respect of an improvement for an owner, contractor or subcontractor" within the meaning of s. 22 and, as part of this analysis, identify the improvement in question. $^{146}$

Grey Owl was retained to provide engineering drawings with respect to storage tanks that were to be used by the contractor or principal subcontractor "as part of their oil extraction system." In such circumstances, it is an error to ask whether the claimant claims a lien in the storage tanks as an "improvement." Applying Hansen, the "improvement" with respect to which the legislation is concerned is the project that will lead to the extraction of oil. ${ }^{147}$

$143 \quad$ Trotter and Morton, supra note 123 at para 39.

144 Supra note 27.

1452015 SKCA 108 [Grey Owl].

$146 \quad$ Ibid at para 18.

$147 \quad$ Ibid at para 36. 
It is worth noting that the wording of Saskatchewan's builders' lien legislation, ${ }^{148}$ in the relevant part, is almost identical to the wording of the $B L A .{ }^{149}$ Further, the Grey Owl decision was approved and applied by the Alberta Court of Queen's Bench in Davidson Well. ${ }^{150}$ There, Justice Ross wrote:

Further, the approach in Grey $\mathrm{Owl}$ is fully in accord with the approach in a number of Alberta Court of Appeal cases, including Schlumberger ... and PTI Group Inc v ANG Gathering \& Processing Ltd

I conclude that both the Alberta Court of Appeal and the Saskatchewan Court of Appeal consider

"improvement" from the perspective of the "overall project" involved. In other words:

(i) the "overall project" is the "improvement";

(ii) the "overall project" constitutes the "thing constructed, erected, built, placed, altered, repaired, improved, added to, dug or drilled or intended to be constructed, erected, built, placed, altered, repaired, improved, added to, dug or drilled on or into, land"; and

(iii) the "overall project" would also be the thing that is "affixed to the land or intended to become part of the land." 151

In Trotter and Morton, Master Prowse also cited a line of Alberta cases that have validated builders' liens filed on the "wrong land." In other words, land that is not the land to which the work or materials were supplied. This is allowable so long as the correct parcel is adjacent to or in close proximity to the liened land and provided that they are part of the same overall project. The consequence of this is that work may be considered to have been done on an "improvement" even where the work was done on another parcel of land and not the parcel that was liened for the intended purpose. ${ }^{152}$

Master Prowse therefore accepted the alternative argument and acknowledged the binding precedent found in Davidson Well, discussed in greater detail below. If the pumphouses could not individually be considered an "improvement" then the improvement was the Horizon Oilsands Project in its entirety. As discussed above in the context of International Brotherhood, this line of reasoning may also expand the scope of interests that one lien registration may encumber. 


\section{DAVidson Well Drilling's Receiver AT THE QUEEN'S BENCH}

In Davidson Well, the Alberta Court of Queen's Bench indicated that general improvements on oil sands mining projects involving the drilling of exploratory oil or gas wells qualified for the extended 90-day lien registration period provided for under section 41 of the BLA. The Court also concluded that the costs of moving equipment away from a project site after it is completed may, in certain circumstances, also be properly included in a builders' lien.

The company Davidson Well Drilling Limited (Davidson) had been contracted to perform geotechnical testing and exploration work on two Syncrude Canada Limited (Syncrude) open-pit mining sites. Importantly, the work involved drilling wells for resource coring to explore the location for bitumen from which oil would be processed. The work was strictly exploratory; there was no mineral extraction or direct recovery of oil and gas from these wells. Davidson proceeded to subcontract with a number of subtrades for drilling and exploration services. These subcontractors ultimately became the lien claimants when Davidson went into receivership in April 2013. By that time, Syncrude had already terminated its agreement with Davidson (25 February 2013).

In its application, the court-appointed receiver for Davidson sought approval of its proposed distribution of lien funds. The lien claimants, Century Wireline Services, Clean Harbors Energy and Industrial Services Corp., 72619 Alberta Ltd. operating as Roughrider International, Bruno's Trucking Ltd., and Acme Energy Services Inc. (collectively, the Lienholders), all brought cross-applications to have their liens declared valid.

\section{STATUTORY FRAMEWORK AND INTERPRETATION}

The primary issue before the Court was whether the work done by the Lienholders related to improvements on an oil or gas well or an oil or gas well site. As Justice Ross notes at the outset, this was an important issue because it determined whether a 45-day or 90-day lien period applied, pursuant to sections 18 and 41 of the $B L A$.

Under section 18, when making a payment on the contract an owner is obligated to retain an amount equal to 10 percent of the value of the work actually done and materials actually furnished for a period of 45 days. However, where the lien is registered "with respect to improvements to an oil or gas well or to an oil or gas well site," that period is extended to 90 days. The right to register a lien is then conferred to the lien claimant pursuant to section 41 of the $B L A$, which imports those same time limits.

The application of sections 18 and 41 is complicated by the fact that the terms "oil or gas well" and "oil or gas well site" are not defined under the BLA. Accordingly, Justice Ross was tasked with interpreting the statute. In so doing, Justice Ross deferred to well-established principles of interpretation, succinctly captured and applied by Master Mason's decision in 
Williams Scotsman of Canada Inc. v. Farm Kitchens Inc. ${ }^{153}$ In Farm Kitchens, Master Mason commented as follows:

(a) Both "oil or gas well" and "oil or gas well site["] are not defined in the BLA;

(b) 'Courts have long adopted Driedger's modern principle as to the method to follow for statutory interpretation:... the words of an Act are to be read in their entire context, in their grammatical and ordinary sense harmoniously with the scheme of the Act, the object of the Act and the intention of Parliament";

(c) "The grammatical and ordinary meaning of the words 'oil or gas well' or 'oil or gas well site' relate to the well itself and the area around the well that serves the extraction process"; and

(d) "Had the legislature intended that a longer lien period be granted to providers of services and materials to [a] broader extent...it could easily have included such language, as it did, for example, in section 6(2) of the Act. There, the Legislature created a lien for the furnishing of work and materials 'preparatory to, in connection with, or for an abandonment operation in connection with the recovery of a mineral'. Such language was not used in section 41(2)(b)."154

Justice Ross also undertook a review of the Alberta Hansard on Bill 22 regarding the Builder's Lien Amendment Act, 2001. There was, however, no definitive answer in the Hansard regarding the scope and extent of the industry practices that were intended to be captured and accommodated within the extended 90-day registration period.

The receiver's position in this case was that "oil or gas well" and "oil or gas well site," which were added following Bill 22, refer to wells drilled for the purpose of producing oil or gas and the sites where such wells are located. Oil sands projects were not described in the amendments to the BLA. The receiver further argued that the Lienholder's work was not done in respect of improvements to such sites. Rather, the Syncrude sites were open pit mines subject to oil sands leases, and the wells drilled by the Lienholders were not for the purpose of extracting oil or gas, but were purely exploratory.

The Lienholders, meanwhile, submitted that interpreting the definition of oil or gas wells to mean only "wells for the production of oil or gas" was not appropriate. They argued that the $B L A$ is not concerned with production of oil and gas. Rather, the intention of the extended lien periods under sections 18 and 41 is to benefit, as conveyed through the Hansard, those "contractors that drill oil and gas wells or service oil and gas well sites."155 It was the activities, and the significance of those activities to the economy of the province, that were important to the legislators. 24.

154 Davidson Well, ibid at para 25, citing Farm Kitchens, ibid.

155 Alberta, Legislative Assembly, "Bill 22, Builders' Lien Amendment Act, 2001," Alberta Hansard, 25-1 (14 November 2001) at 1056 (Hon Denis Ducharme), cited in Davidson Well, ibid at para 27. 


\section{DECISION IN RESPECT OF THE LIEN PERIOD}

The Court agreed with the Lienholders, finding that the 90-day lien period for improvements to an oil or gas well or to an oil or gas well site required a liberal interpretation, consistent with the remedial purpose of the BLA. Justice Ross concluded as follows:

In my view, this interpretation best accords with the language and purpose of the $B L A$. To the extent that there may be ambiguity, it finds further support in the principle calling for a liberal interpretation of provisions of the $B L A$ regarding the scope of lien rights. ${ }^{156}$

As described above and echoed by Master Prowse in Trotter and Morton, Justice Ross also noted that both the Alberta Court of Appeal and the Saskatchewan Court of Appeal considered 'improvement' from the perspective of the 'overall project' involved. ${ }^{157}$ Accordingly, even in the case of Roughrider International's on-demand equipment maintenance services, work performed in connection with the improvement of the sites invited the right to register a lien under the BLA.

For greater certainty, Justice Ross held that this conclusion accords with the liberal approach in a number of Alberta Court of Appeal cases, namely Schlumberger Holdings (Bermuda) Limited. v. Merit Energy Ltd. ${ }^{158}$ P.T.I. Group Inc. v. ANG Gathering \& Processing Ltd. ${ }^{159}$ and Alberta Gas Ethylene Company Ltd. v. Parkland Ventures. ${ }^{160}$ As discussed above, this also applies to the principles set out in Grey Owl by the Saskatchewan Court of Appeal. ${ }^{161}$

The Court further accepted that the Alberta Hansard record indicated that the 90-day lien period was enacted by the Alberta Legislature to accommodate the unique industry payment practices affecting contractors that drill oil and gas wells or service oil and gas well sites. The Court held that nothing in Hansard or the language of the BLA suggested that the lien rights of drillers should be restricted based on the location of their work. The Court further found that, in this case, the drilling of exploratory oil or gas wells was for the purpose of locating bitumen, from which oil would be processed, therefore bringing the exploratory wells "within the ordinary and grammatical meaning of oil or gas wells." 162 The "potential" that oil or gas could be discovered was enough. ${ }^{163}$ Consequently, the applicable lien period was 90 days.

Davidson Well, ibid at para 45.

Ibid at para 79; see also Trotter and Morton, supra note 123 at para 54.

2001 ABCA 190 [Schlumberger].

2002 ABCA 89.

(1979), 20 AR 459 (CA).

Grey Owl, supra note 145.

Davidson Well, supra note 149 at para 40.

Ibid. 


\section{DemobiLization Costs as Part OF THE LiEN}

The Court made secondary findings respecting amounts claimed under the liens for standby and demobilization costs. Justice Ross referred to the Husky Oil Operations Limited v. Ledcor Industries Limited ${ }^{164}$ and Schlumberger cases, in which it was found that transportation of equipment to a site was essential to the performance of work on an improvement. However, the Court did not apply the same reasoning to the transportation of equipment away from a site. In her analysis, Justice Ross arrived at a different conclusion by reviewing Schlumberger and finding, instead, that equipment is required on a temporary site for the purpose of construction and essential to the completion of the improvement.

In Husky Oil this Court held that the cost of removing equipment from a site did not give rise to lien rights. The Court noted that the Alberta Court of Appeal in Schlumberger Holdings (Bermuda) Ltd v Merit Energy Ltd ... held that the cost of transportation of equipment to a site is essential to the performance of work on an improvement, but declined to apply the same reasoning with respect to the costs of removing equipment from the site. With respect, I disagree. In my view, it clearly follows from the reasoning in Schlumberger that transportation costs of equipment from the site are properly included in a builder's lien. Where equipment is required on site on a temporary basis for the purpose of construction, it is essential to completion of the improvement both that the equipment be delivered to the site when it is needed, and that it be removed from the site afterwards. ${ }^{165}$

Consequently, both the delivery of the equipment and the removal from a site afterwards can give rise to lien rights. The Court in this case found that both standby and demobilization costs could be included in the Lienholders' claims.

\section{THOUGHTS AND REFLECTIONS}

Davidson Well is an important interpretive tool for ascribing meaning to the terms "oil or gas well" or "oil or gas well site" in the context of the BLA. The meaning prescribed to these terms can have a significant impact on rights under the $B L A$. Alberta courts have held that the Alberta Legislature intended to accommodate the unique circumstances of billing and payment cycles in the oil and gas industry and to give a wide range of industry participants more time.

This decision is significant for oil sands project owners, contractors, and subcontractors alike. The Court found that the drilling work done on the exploratory wells in question constituted preparatory services for improvements to an "oil or gas well" or "oil or gas well sites," where even the mere possibility of discovering oil or gas exists. There will still be non-drilling-related work on oil sands sites subject to the 45-day lien period, but Davidson Well offers a generous interpretation that may extend the extra time to preparatory steps in the construction of a well site. Again, however, where work is not obviously related to 
drilling or servicing an oil or gas well or site it would remain to be best practice to register a builders' lien within the 45-day lien period.

Justice Ross acknowledged that her conclusions would create situations where different types of work performed on the same well site would invite different registration deadlines. This is, however, simply "a natural consequence of the legislation" 166 that encourages project proponents to pay careful attention to the nature and scope of the services being provided to a well site.

\section{Arbitration: Choose your JuRisdiction Wisely}

Fighting a legal battle on multiple fronts can be onerous. Depending on the nature and scope of the dispute, these proceedings can be related to the same facts and can quickly become prohibitively expensive. The risk of a multiplicity of proceedings has divided Canadian courts. On the one hand, some provincial courts have held that arbitration agreements must be strictly enforced. In other provinces, the courts have taken a more liberal approach.

Due to the many benefits of arbitration, it is common to integrate arbitration clauses into construction project contracts. One such benefit is that arbitration is fundamentally a consensual process, where the contracting parties can opt to decide how disputes will be resolved. In complex disputes, which are often the case in the construction industry, arbitration may create competing interests between parties who have consented to arbitration and third parties who are not subject to the same arbitration clauses. By contrast, the traditional litigation process operates without requiring any party's consent. This difference creates a risk of a multiplicity of proceedings taking place simultaneously in different forums.

\section{A. THE "NEW ERA" AND FLATIRON}

In Canadian Natural Resources Limited v. Flatiron Constructors Canada Limited, ${ }^{167}$ the Alberta Court of Queen's Bench considered when an arbitration ought to be stayed in favour of an action. Ultimately, the Court held that under certain circumstances there is a residual discretion in Alberta to allow for an arbitration to be stayed in favour of a court action.

Specifically, this case involved Canadian Natural Resources Limited (CNRL) expanding its Horizon Oil Sands Project extraction facility in 2012. Flatiron Constructors Canada Limited (Flatiron) was hired as the general contractor and asked to, among other things, supply and install four tailings thickener tanks, two of which included mechanically stabilized earth walls (MSE Walls). Almost immediately after substantial completion, two failures occurred wherein the MSE Walls collapsed, causing damage to the system. 
The parties could not agree on the cause of the failures, nor to the compensation that would be due for performing the remediation. Nonetheless, remedial work had to be undertaken. Accordingly, CNRL and Flatiron entered into a Cost Sharing Agreement (CSA) so that Flatiron could proceed with the remedial work under protest and so that CNRL would provide some funding for any amount not covered by insurance.

The CSA included an arbitration clause:

[U]ltimate responsibility of the Remedial Costs will ... be resolved ... in accordance with the Arbitration Process. In the event that the Dispute is not resolved by any settlement between the Parties and either the Insurance Claims have been denied or there is a Shortfall, then either Party may submit this matter to arbitration in accordance with the Arbitration Process by no later than 9 months from the date of this CSA. ${ }^{168}$

At the time of the hearing, insurance coverage had not been denied. A substantial amount of the cost of the remedial work had been accepted and paid by the insurers. A number of insurance claims remained outstanding, but were still being adjusted. Neither CNRL nor Flatiron knew the final amount of insurance coverage they would receive, and consequently could not determine if there was a shortfall. Further, though litigation against the insurers might have later arisen, it was suspended through a Tolling Agreement.

Flatiron commenced an action against the various contractors and subcontractors who had allegedly contributed to, or caused, the failure of the MSE Walls. Flatiron also commenced an arbitration against CNRL, levying the same allegations and seeking the same damages. CNRL brought an Originating Application seeking a stay of the arbitration commenced by Flatiron until a decision in the action was rendered. CNRL asserted that: (1) the arbitration was premature, and (2) it would be duplicative and risk inconsistent determinations on the same issues.

\section{1. $\quad$ Alberta Courts Apply the Test Set out in NEW ERA}

Associate Chief Justice Rooke accepted that the arbitration had likely been commenced prematurely. However, he was not required to interfere with it on those grounds because, in short, staying the arbitration would preserve any contractual limitation periods to which Flatiron might be subject, while simultaneously preventing the arbitration from moving forward. Associate Chief Justice Rooke also held that the arbitration may yet become necessary to adjudicate issues not dealt with in the court proceeding, but that dealing with those issues after the fact would streamline the process. ${ }^{169}$ 
The crux of the matter was decided on Associate Chief Justice Rooke's conclusion that the arbitration and action had duplicative and overlapping aspects. Accordingly, the preponderance of case law supported CNRL's assertion that, in Alberta, duplicative arbitration proceedings should be stayed. ${ }^{170}$

In New Era, the Alberta Court of Appeal addressed the circumstances under which a court is entitled to stay an arbitration in favour of an action. ${ }^{171}$ While section 7 of the Alberta Arbitration Act, ${ }^{172}$ holds that an action must be stayed in favour of an arbitration except under limited circumstances, the Court of Appeal interpreted section 6 of the $A B A A$ to provide an overriding discretion to prevent manifestly unfair or unequal treatment of a party to an arbitration agreement. Justice Conrad succinctly concluded in New Era as follows:

\footnotetext{
I take all of these factors to mean that the Legislature intended that the courts use subsection 6(c) to provide a remedy to cure unfairness arising from matters not covered by the specific language of the legislation. In my view, it would be manifestly unfair to deny the remedy contemplated by section 7 which is designed to protect against the dangers inherent in duplicitous proceedings. It is an uncommon situation where a party seeks to both sue and arbitrate. Frequently the dangers inherent in duplicitous actions arise when some parties are covered by an arbitration clause and others are not. I am satisfied that subsection 6(c) allows a party, faced with both a statement of claim and a notice to arbitrate, to apply to stay the arbitration on the basis that the matters in the two proceedings overlap and cannot be reasonably separated. ${ }^{173}$
}

This, however, is not universally accepted. Ontario has adopted the New Era approach. ${ }^{174}$ As will be discussed below, the Saskatchewan Court of Appeal has rejected the New Era approach and endorsed a strict interpretation to staying court proceedings unless, and only if, the specific circumstances contemplated in Saskatchewan's Arbitration Act, 1992, ${ }^{175}$ are met.

In Flatiron, Associate Chief Justice Rooke agreed that the continuation of the arbitration would be oppressive and prejudicial to CNRL. ${ }^{176}$ Consequently, the arbitration was stayed in favour of the court proceeding. The arbitration would not have provided the parties with the proper access to evidence (witnesses and documentary) and would not have allowed Flatiron and CNRL to determine the ultimate cause of the failure of the MSE Walls. By proceeding with the court action, the parties could later resolve any remaining issues through arbitration. seminal Alberta Court of Appeal decision in New Era Nutrition Inc v Balance Bar Company, 2004 ABCA 280 [New Era], for the applicable test to stay arbitral proceedings.

New Era, ibid.

RSA 2000, c A-43 [ABAA].

New Era, supra note 170 at para 43.

Griffin v Dell Canada Inc, 2010 ONCA 29 at para 49.

SS 1992, c A-24.1 [SKAA].

Flatiron, supra note 167 at para 53. 


\section{SASKATCHEWAN'S CONTRARY OPINION}

In Saskatchewan Power Corporation v. Alberici Western Constructors, Ltd. ${ }^{177}$ the Saskatchewan Court of Appeal addressed, but disagreed, with the New Era test. Chief Justice Richards wrote as follows:

\footnotetext{
Further, in my respectful view, New Era over-reads the relevant provisions of the Arbitration Act. As explained by the Chambers judge in the Court below, provisions like s. 7(c) must be understood in light of the underlying theme of the Act which is that, when parties freely contract to resolve disputes by arbitration, courts should give effect to those commitments. See: Seidel v Telus Communications Inc., 2011 SCC 15 at para 2, [2011] 1 SCR 531. As explained above, on its face s. 7(c) is aimed at ensuring the internal integrity of arbitration proceedings, not at displacing such proceedings in favour of litigation. ${ }^{178}$
}

Therefore, in Saskatchewan, an arbitration agreement will be given precedence, and a court action will be stayed, unless the factors listed in section 8(2) of the SKAA are met. According to Chief Justice Richards, "the prospect of a multiplicity of proceedings is not a valid reason for refusing to refer a dispute to arbitration." 179 To do otherwise would be contrary to what he understood to be the legislature's intent.

\section{The Supreme Court of CANAdA Chimes In}

In the recent decision of TELUS Communications Inc. v. Wellman, ${ }^{180}$ the Supreme Court of Canada had occasion to discuss the Ontario equivalent to section 6(c) of the $A B A A$. In that case, the Supreme Court of Canada was considering whether to certify a proposed class action.

A portion of the proposed class were private citizens, covered by consumer protection legislation, while the other portion of the class were businesses not protected by the same legislation. All members of the proposed class had entered into contracts with TELUS that contained a mandatory arbitration clause. TELUS therefore sought to have the portion of the class action proceeding relating to the businesses stayed, as those claimants were not protected by the consumer protection legislation and would be required to pursue individual arbitrations on their own. 
In relevant part, when addressing whether section 6-3 of the Ontario Arbitration Act, $1991,{ }^{181}$ would allow for the class action proceeding to continue, the majority had the following to say:

Furthermore, while I agree that s. 7(5) should be read in the context of the statutory scheme as a whole and that s. 6-3 permits the court to intervene "[t]o prevent unequal or unfair treatment of parties to arbitration agreements", I also note that s. 6 allows such intervention only "in accordance with this Act". Therefore, even though Mr. Wellman's interpretation of s. 7(5) would ostensibly give the court greater scope to intervene in an effort to prevent perceived unequal or unfair treatment of parties to arbitration agreements, the words "in accordance with this Act" indicate that s. 6 was not intended to override or change the meaning of other sections of the Arbitration Act. ${ }^{182}$

Though not on all fours, it appears that the Supreme Court of Canada may therefore favour the more restrictive Saskatchewan Court of Appeal approach from Alberici. A challenge to the New Era approach may be forthcoming.

\section{Thoughts AND ReFlections: CONFLiCTING InTERESTS AT Play}

Despite the foregoing, the New Era test relates to applications to stay an arbitration. It is not meant to address an application under section 7 of the $A B A A$ to stay a court proceeding. Alberta courts are still bound to uphold arbitration clauses. ${ }^{183}$ Even under section 6 of the $A B A A$ the starting position is non-intervention. ${ }^{184}$ Further, if an applicant seeks to stay the court proceeding under section 7 of the $A B A A$, then an Alberta judge must stay the action in favour of the arbitration unless the circumstances are such that one of the listed exceptions under section 7 of the $A B A A$ exists. ${ }^{185}$ Neither New Era nor Flatiron dealt with a competing application to stay the action. In light of the TELUS decision, it will be interesting to see how the court in Alberta might resolve such a circumstance.

There are sound policy reasons for avoiding a multiplicity of proceedings. As pointed out by Associate Chief Justice Rooke, parties and non-party witnesses will wish to avoid a duplication of time and costs. ${ }^{186}$ Further, it is trite law that a plaintiff is supposed to claim all their damages in a single action and re-litigating the same issues in multiple proceedings is an abuse of process. ${ }^{187}$ Perhaps most importantly, a multiplicity of proceedings can jeopardize the administration of justice by allowing "inconsistent determinations by different decision makers on similar or identical issues." $" 188$

181 SO 1991, c 17 [ONAA].

TELUS, supra note 180 at para 75 .

Flatiron, supra note 167 at para 45.

Epcor Power LP v Petrobank Energy and Resources Ltd, 2010 ABCA 378 at para 18.

UCANU Manufacturing Corp v Graham Construction and Engineering Inc, 2013 CarswellAlta 2979

(WL Can) at para 44 (QB).

Flatiron, supra note 167 at para 38.

Ibid at para 21.

Ibid at para 39. 
In opposition to this are concerns regarding the limited resources of the justice system, the desirability of allowing parties to resolve their disputes efficiently, and the underlying importance of giving effect to the bargains struck between contracting parties. As Associate Chief Justice Rooke commented,

this is not a case where the Court is being asked to intervene, or is in fact intervening, to abrogate the right by agreement of parties to arbitrate a dispute. If the same issues were between the same parties, any such agreement should, in my view, have precedence, absent other limiting factors. ${ }^{189}$

Allowing a party to an arbitration agreement to escape their contractual obligations by simply commencing a court action runs contrary to all business sense. ${ }^{190}$

\section{B. Dealing With Multiple Litigants: Seeking to Commence Consolidated Arbitrations}

Staying proceedings and the risk of a multiplicity of proceedings significantly impacts contracting parties when the prospect of litigation with multiple parties arises. In some circumstances, businesses can be faced with proceedings involving dozens of litigants across multiple forums. Both the Alberta and British Columbia Courts of Appeal have recently dealt with a crucial concept related to these issues: commencing omnibus arbitrations.

\section{SOUTH COAST AND THE LIMITS OF \\ CONSOLIDATING MultiPle ARBitrations}

In South Coast British Columbia Transportation Authority v. BMT Fleet Technology Ltd. ${ }^{191}$ the British Columbia Court of Appeal considered whether the Respondent's notice, that purported to commence a quadripartite arbitration under the British Columbia Arbitration Act, ${ }^{192}$ before one arbitrator, under four different contracts, absent the consent of the responding parties, was valid. In the unique context of the $B C A A$, the trial judge held that it was valid. However, the British Columbia Court of Appeal ultimately concluded that the notice to arbitrate was not curably irregular and was therefore a nullity. ${ }^{193}$

In this case, the South Coast British Columbia Transportation Authority (TransLink) contracted with each of the four parties with whom they intended to commence an omnibus arbitration for the construction of a new passenger ferry for TransLink's SeaBus service. Each of the contracts contained an arbitration clause that stipulated disputes had to be, "settled by arbitration under the Commercial Arbitration Act [now simply the Arbitration Act $]$ of British Columbia." 194 Section 22 of the BCAA states that unless the parties agree 
otherwise, the rules of the British Columbia International Commercial Arbitration Centre (the Centre) for the conduct of domestic commercial arbitrations apply.

A dispute arose several years after the passenger ferry had been in commercial operation. TransLink sent a notice to arbitrate to the Centre, naming three of the contractors as "Parties to the Dispute." The fourth was left out on account of a slight variance in its arbitration clause. When the responding contractors refused to accept the validity of the notice to arbitrate, TransLink filed a petition in the Supreme Court of British Columbia seeking a declaration that the arbitration had been properly commenced and the appointment of an arbitrator. The trial judge granted TransLink's request.

On appeal, the named contractors submitted that the notice to arbitrate was fatally noncompliant with the BCAA. By purporting to start a multi-party, multi-contract arbitration without the individual agreement of the parties at the time of contracting, the notice was contrary to the very concept of arbitration underlying the BCAA. They pointed to section 21 of the $B C A A$ as evidence that consent was a prerequisite to consolidating multi-party disputes into a single arbitration proceeding. ${ }^{195}$ Though differently worded, provisions to a similar effect are present in other provincial arbitration acts. ${ }^{196}$

The appellant's reasoning was persuasive to the Court of Appeal. Central to its decision were the intrinsic features of arbitration clauses. Justice Saunders held that fundamental to any arbitration is an agreement between the parties that they will resolve the matter in a private dispute, in front of arbitrator of their choice, and subject to an agreed-upon process. She went on to explain:

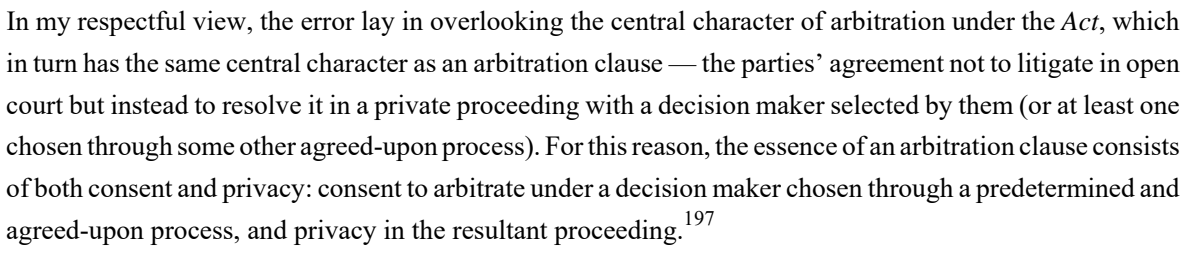

TransLink sought to initiate a procedure different from that which the parties had individually and separately each agreed to. This ran contrary to the "root' of the parties' rights inter se." ${ }^{\prime 198}$ Justice Saunders concluded, following a review of the relevant authorities, that apart from statute, an arbitration may only apply in the manner agreed to by the

Under section 21 of the BCAA, supra note 192 :

Disputes that have arisen under 2 or more arbitration agreements may be heard in one arbitration if (a) the disputes are similar, and (b) all parties to those agreements agree on the appointment of the arbitrator and the steps to be taken to consolidate the disputes into the one arbitration.

ABAA, supra note 172, s 8(4) ("all the parties"); SKAA, supra note 175, s 9(4) ("all the parties"); ONAA supra note 181, s 8(4) ("all the parties").

South Coast, supra note 191 at para 31.

Ibid at para 32, citing South Coast British Columbia Transportation Authority v BMT Fleet Technology Ltd, 2017 BCSC 1683 at para 89. Definition: "inter se" means "between or among themselves" (Bryan A Garner et al, eds, Black's Law Dictionary, 10th ed (St Paul, Minn: Thomson Reuters, 2014) sub verbo "inter se"). 
parties. ${ }^{199}$ Section 21 of the BCAA did not allow for the consolidation of separate arbitrations without the consent of the parties, any more than the contracts did.

\section{AUTHORITY IN AlBERTA FOR THE CONSOLIDATION OF ARBITRATIONS UNDER THE LEGISLATION}

Notably, Justice Saunders identified in South Coast that an arbitration agreement may only address the disputes contemplated within the contract, unless the relevant legislation provides otherwise. ${ }^{200}$ The relevant section of the BCAA in that case was section 21 , which states that disputes arising under two or more arbitration agreements may be heard together "if (a) the disputes are similar, and (b) all parties to those agreements agree on the appointment of the arbitrator and the steps to be taken to consolidate."201

In South Coast, Justice Saunders addressed whether a single party could, pursuant to section 21 of the $B C A A$, move to have multiple arbitrations consolidated. However, TransLink had not invoked section 21 of the BCAA and the issue was not central to the decision. Nonetheless, following her interpretation of the use of the plural, being the requirement that "all parties to those agreements agree," Justice Saunders accepted that consent of the parties was required in order to consolidate multiple arbitrations.

By contrast, judicial consideration of similar wording contained within the Alberta International Commercial Arbitration $\mathrm{Act}^{202}$ has resulted in divergent outcomes. Consequently, there is support for the proposition that a single party may, in Alberta, apply to the court for the consolidation of multiple arbitrations.

Section $8(4)$ of the $A B A A$ provides that the court may consolidate separate arbitrations, "[o]n the application of all the parties to more than one arbitration." ${ }^{203}$ On its face, it is conceivable that the $A B A A$ would therefore require the consent of the parties, as was the case in South Coast. However, in Pricaspian Development Corporation v. BG International Ltd. ${ }^{204}$ Chief Justice Wittmann considered section $8(1)$ of the ICAA, which mirrors section $8(4)$ of the $A B A A$.

In Pricaspian, Chief Justice Wittmann took into account section 26(3) of the Interpretation $A c t,{ }^{205}$ and concluded that a singular party may bring an application in order to have the matter of consolidation determined on the merits. Accordingly, when considering the meaning of "on application of the parties" in section 8(1)(a) of ICAA, Chief Justice Wittmann determined consent of all the parties was not required. The crux of Chief Justice Wittmann's decision hinged on the fact that the Interpretation Act made it clear that words

South Coast, ibid at para 40.

Ibid at para 41.

BCAA, supra note 192.

RSA 2000, c I-5 [ICAA].

Supra note 172.

2016 ABQB 611 [Pricaspian].

Interpretation Act, supra note 126, s 26(3): "In an enactment, words in the singular include the plural, and words in the plural include the singular." 
in the plural include the singular. So in the ICAA, and arguably in the $A B A A$, where it states simply that "on application of the parties" it is appropriate that a single "party" bring an application for consolidation of multiple arbitrations.

A closer look at section 21 of the $B C A A$ reveals a clear difference in the wording. For example, in section 21 of the BCAA states, "if ... all parties to those agreements agree." The Alberta legislation does not contain the same express requirement for agreement. While consolidation need not be automatically granted, the Court in Pricaspian reserved a residual judicial discretion to consider the merits of the motion.

In Commercial Arbitration in Canada: A Guide to Domestic and International Arbitrations, the authors point to a number of important features of Chief Justice Wittmann's decision in Pricaspian, as follows:

\begin{abstract}
Among other things, the court suggested that different language would likely have been used (such as "joint application" or "application by agreement of parties") if legislators had intended for the application to have to be consented to, "[g]iven that it would be very uncommon for a joint or consented to application to even be made." The court also pointed out that s. 8(3) provides that the parties could agree to consolidate and take necessary steps to effect that consolidation, and noted that "[t]here would be no reason for these two separate subsections to exist if both dealt with an agreement between parties: one must necessarily deal with disagreement: s. 8(1).,206
\end{abstract}

Priscapian more recently received support in Japan Canada Oil Sands Limited v. Toyo Engineering Canada Ltd. $^{207}$ where after a lengthy review of the relevant case law, Justice Romaine wrote:

I find the reasoning of Wittmann, CJ in Pricaspian to be persuasive, and I agree that section 8(1) of the ICAA allows an application for consolidation to be brought by one party to the arbitration. Therefore, if I am wrong on the issue of Toyo Canada's consent to consolidation, I would in any event find the jurisdiction to decide the application.

Although Toyo Japan has not consented to consolidation, I find that I have the jurisdiction to decide the application with respect to its participation in a consolidation. ${ }^{208}$

It seems that Alberta's arbitration legislation may operate differently from that of British Columbia.

J Kenneth McEwan \& Ludmila B Herbst, Commercial Arbitration in Canada: A Guide to Domestic and International Arbitrations (Toronto: Thomson Reuters, 2017) (looseleaf updated December 2018, release 16) at 6:70.20 [footnotes omitted]. 2018 ABQB 844 [Japan Oil]. Ibid at paras 108-109. 


\section{ThOughts AND ReFlections: A CAREFul CHOICE}

South Coast makes it clear that a party wishing to commence omnibus arbitrations, giving it the ability to have multiple disputes consolidated with a single notice, must do so expressly in the contract at the time of formation. Failing to properly include consolidation parameters within the arbitration provisions of a contract may eliminate the option to avoid litigating similar or related issues in multiple proceedings, a prospect that may have a wider and negative impact on the administration of justice.

While there is support for the fact that an application for consolidation under the ICAA may be available on application of a single party, the issue depends heavily on the arbitration agreement under review and the specific words of the jurisdiction's applicable legislation.

Arbitration agreements can provide many advantages, but procedural challenges that stem from unclear terms can create strategically treacherous territory for a party facing multiple claims in multiple forums. It is important, therefore, to weigh the risks and benefits of arbitration against the robust system of rules that come from traditional litigation.

\section{Settling With Some, But Not Others: The IMPaCt OF Pierringer Agreements}

In Canadian Natural Resources Limited v. Wood Group Mustang (Canada) Inc. (IMV Projects Inc.), ${ }^{209}$ the Alberta Court of Appeal refused to upset the rule in Bedard v. Amin ${ }^{210}$ (the Rule in Bedard), but held that "[ $t]$ he rule against overcompensation should be applied generously in favour of the settling plaintiff." 211 The plaintiff was, therefore, entitled to deduct its costs in pursing settlement and litigation with the settling defendants from the amounts it received in settlement before calculating whether there was an "over-payment" and if the non-settling defendant was entitled to any credit. The Court concluded that any abolition of the Rule in Bedard, and corresponding adoption of a new approach, should be established by the Supreme Court of Canada or the legislature. ${ }^{212}$

\section{PIERRINGER AGREEMENTS GENERALLY}

A Pierringer agreement is an instrument where the plaintiff enters into final settlements with some of the defendants, who are released from the litigation, but proceeds against the non-settling parties. The name is derived from the seminal case: Pierringer v. Hoger. ${ }^{213} \mathrm{In}$ this arrangement, the settling defendants agree to pay a sum of money and are released from the action while the plaintiff agrees not to pursue the non-settling defendants for more than their proportionate liability. Since the non-settling defendants cannot be liable for more than

2018 ABCA 305 [Mustang].

2010 ABCA 3 [Bedard].

Mustang, supra note 209 at para 148.

Ibid.

124 NW (2d) 106 (Wis Sup Ct 1963). 
their proportionate share of the damage, the settling defendants are not exposed to any claim for contribution from the non-settling defendants.

Pierringer agreements can be contrasted against another similar type of agreement: the Mary Carter agreement. In that case, the name of the agreement came from the seminal case Booth v. Mary Carter Paint Co. ${ }^{214}$ In this form of settlement agreement, the plaintiff is guaranteed a fixed recovery from the settling defendants, but the settling defendants remain parties to the action and seek to maximize recovery from the non-settling defendants. This is because the settling defendants will only ever pay a maximum stipulated amount, but that amount is reduced in direct proportion to any increase in the non-settling defendants' liability, as determined at trial.

\section{BACKGROUND}

In Mustang, CNRL contracted with Flint Field Services to install a $32 \mathrm{~km}$ Emulsion Pipeline between its Primrose East Plant and its Wolf Lake Plant. IMV Projects provided the associated engineering and Shaw Pipe supplied the pipe system. The Emulsion Pipeline had a life expectancy of 30 years, but failed after three months of operations.

On the eve of the trial, CNRL entered into a Pierringer agreement with Shaw Pipe and Flint Field Services, but the action proceeded against the non-settling party, IMV Projects. Pursuant to the Pierringer agreement, CNRL released Flint Field Services and Shaw Pipe from the litigation and agreed not to pursue IMV Projects for more than its proportionate share of the liability. The trial judge found that each of CNRL, IMV Projects, Shaw Pipe and Flint Field Services shared in the blame. She set CNRL's damages at \$45,425,204 and apportioned liability. ${ }^{215}$ The Alberta Court of Appeal ultimately varied the trial judge's findings with respect to the apportionment, but not the quantum, and settled on the liability of the parties as follows: 25 percent to CNRL, 35 percent to IMV Projects, 35 percent to Shaw Pipe, and 5 percent to Flint Field Services. ${ }^{216}$

\section{THE RULE IN BEDARD AND AVOIDING A WiNDFALL}

Some of the key issues that arose from the Pierringer agreements in Mustang related to potential outcomes in the case of the settling defendants paying more than they would have had to pay following a decision. The question being considered was, if that were to occur, whether CNRL was required to give a "credit" for that overpayment to the non-settling defendant(s). Such "credit" would effectively reward the non-settling defendant and excuse it from paying the full amount that the court determined it owed. Alternatively, it could be that CNRL would be entitled to recover the full amount of its judgment against the non- 
settling defendant(s) and potentially recover more than the Court awarded to it. This would create a windfall for the plaintiff, as they received more than the total trial award.

Underpinning these issues is the rule against double recovery and the Rule in Bedard, which provides that the plaintiff must account to the non-settling defendants if it "over settled." 217 After canvassing many persuasive arguments for and against the rule that a settling plaintiff must account to the non-settling defendant for any recovery in excess of the actual damages awarded at trial, the Alberta Court of Appeal determined that it was not prepared to abolish the Rule in Bedard. As the Court noted, "[t]he law as it stands represents a curious balancing of preventing overcompensation and encouraging settlement." 218 The arguments canvassed included:

- $\quad$ Settling plaintiffs face the risk of receiving less than they would at trial. The Rule in Bedard places further "risk of a Pierringer settlement ... on the plaintiff. If the plaintiff 'under-recovers' from the settling defendants, it will not be able to make up that shortfall from the non-settling defendants. On the other hand, if the plaintiff 'over-recovers' from the settling defendants ... it will not be allowed to keep the surplus." 219

- $\quad$ By preventing the plaintiff from keeping any over-settlement, the non-settling defendants receive a credit and in effect an incentive not to settle. ${ }^{220}$

- "There [is] no policy reason for reducing the responsibility of the non-settling defendant for the damage it caused"; a defendant found to have caused damage should not get a discount on its wrongdoing. ${ }^{221}$ Conversely, a plaintiff should not receive more money than what the court ultimately determines it is owed.

- $\quad$ Any alleged "“surplus' [is] not truly the proceeds of the cause of action, rather it [is] the consideration under a separate contract, the accord and satisfaction represented by the Pierringer agreement. As such, there [is] no actual double recovery, and the plaintiff should not have to give credit."222

- "Once the settling defendant withdraws from the litigation, the plaintiff loses any incentive to prove it responsible for the damage, thereby shifting the burden of proof to the non-settling defendant." 223 Further, it gets more difficult for the non-

218 Mustang, supra note 209 at para 147, citing Neil G Wilson, "Encouraging Settlement vs. Precise Compensation: Sable Offshore v. Ameron, IBMv. Waterman, and the Future of Mary Carter/Pierringer Settlement Deductibility" (2015) 68 SCLR (2d) 429 at 447.

Ibid.

Ibid at para 142 . 
settling defendant to shift blame when a settling defendant is released from the litigation and no longer participates in the fact finding processes. ${ }^{224}$

- Other courts, in particular in British Columbia and Ontario, have adopted the same approach as the Rule in Bedard. ${ }^{225}$

Ultimately, in this case, the Court struck a compromise by applying the rule against overcompensation generously in favour of the plaintiff. Hence, CNRL was entitled to reduce the amount of its settlements by the costs it incurred to pursue the settling defendants. As illustrated below, had it not been for the deduction of its legal costs then CNRL would have "over settled" and IMV Projects would have been entitled to a credit. Because the trial judge's apportionment of liability was less favourable to CNRL, the Court illustrated that CNRL "under settled" even in a best-case scenario for IMV Projects. The numbers were as follows: 226

Damages: $\$ 45,425,204$

\begin{tabular}{|c|c|c|c|c|}
\hline & CNRL & $\begin{array}{l}\text { IMV Projects } \\
\qquad(20 \%)\end{array}$ & $\begin{array}{c}\text { Shaw Pipe } \\
(25 \%)\end{array}$ & $\begin{array}{l}\text { Flint Field Services } \\
\qquad(5 \%)\end{array}$ \\
\hline Trial Award & $\$ 22,712,602$ & $\$ 9,085,040$ & $\$ 11,356,301$ & $\$ 2,271,260$ \\
\hline Pierringer & & & $\$ 14,500,000$ & $\$ 4,000,000$ \\
\hline Interest & & & $\$ 213,250$ & $\$ 42,650$ \\
\hline Legal Costs & & & $\$ 3,591,471$ & $\$ 1,966.070$ \\
\hline Take Home & & & $\$ 10,695,279$ & $\$ 1,991,280$ \\
\hline Delta (approx) & & & $\begin{array}{r}\$ 661,000 \\
\text { (Under Settled) }\end{array}$ & $\begin{array}{r}\$ 280,000 \\
\text { (Under Settled) }\end{array}$ \\
\hline
\end{tabular}

\section{ThOUGHTS AND REFLECTIONS}

It seems counterintuitive for a plaintiff to be required to provide a credit to a non-settling defendant where they have "over settled" with the other settling defendants. However, the rule against double recovery is pervasive and fundamental. As a compromise, at least, the Rule in Bedard was applied generously in favour of the plaintiff. Arguably, this decision will still discourage and disincentivize settlement. Where a plaintiff "under settles" it will not be entitled to pursue the settling defendants for the shortfall. Care should be taken to ensure

226 Ibid at paras 122-25, 191. It appears that because the Alberta Court of Appeal decreased CNRL's liability, and increased the liability of IMV projects and Shaw Pipe, it did not bother working with the new totals when comparing the settlement amounts against the damage awards. If anything, the increased amount owing to CNRL would have eliminated any concern that it had received a windfall and would have further affirmed that it "under settled" with the settling parties. 
settlements, especially in complex multi-party arbitrations or actions, are not exposing the settling plaintiff to additional risk.

\section{Conclusion}

In the oft-cited passage from Packer v. Packer, Lord Denning stated that: "If we never do anything which has not been done before, we shall never get anywhere. The law will stand still while the rest of the world goes on, and that will be bad for both." 227

Where compelling reasons exist to alter the existing legal landscape, courts of all levels should take charge. The common law should be crafted under the careful guidance of our Judges and Masters. Incremental changes in the law are not only good and desirable, but necessary. However, where significant leaps are taken, large gaps in application can emerge, and it falls to industry and government to adjust accordingly.

The oil and gas industry will continue to be a driving force in the development of construction law and construction will, both literally and figuratively, continue to shape the oil and gas industry. Bonding, liens, tendering, and arbitrations are only a few of the intersections between oil and gas and construction law. Through the continuation of our adversarial legal system, these relationships will continue to deepen.

With the law as it stands, challenges remain to be made and inconsistencies remain to be addressed. Identifying what factors have informed the decisions to date helps predict how the law will continue to develop. In some instances, the dissenting opinion of today is the majority decision of tomorrow. Accordingly, it is important to trace the golden thread of logic that weaves itself through the interconnected web of precedent, legislation, and private arrangements. 